NBER WORKING PAPER SERIES

\title{
THE IMPACT OF EARLY INVESTMENTS IN URBAN SCHOOL SYSTEMS IN THE UNITED STATES
}

\author{
Ethan J. Schmick \\ Allison Shertzer \\ Working Paper 25663 \\ http://www.nber.org/papers/w25663 \\ NATIONAL BUREAU OF ECONOMIC RESEARCH \\ 1050 Massachusetts Avenue \\ Cambridge, MA 02138 \\ March 2019, Revised March 2020
}

We are grateful to Vellore Arthi, Leah Boustan, Louis Cain, Karen Clay, Jason Cook, Katherine Eriksson, James Feigenbaum, Andreas Ferrara, Osea Giuntella, Claudia Goldin, Walker Hanlon, Kirabo Jackson, Shawn Kantor, Elyce Rotella, Edson Severnini, Lowell Taylor, Werner Troesken, Randall Walsh, and seminar participants at the NBER Summer Institute (DAE), Rhodes College, the Tepper applied micro lunch, Illinois, and the World Economic History Congress for helpful comments. The views expressed herein are those of the authors and do not necessarily reflect the views of the National Bureau of Economic Research.

NBER working papers are circulated for discussion and comment purposes. They have not been peer-reviewed or been subject to the review by the NBER Board of Directors that accompanies official NBER publications.

(C) 2019 by Ethan J. Schmick and Allison Shertzer. All rights reserved. Short sections of text, not to exceed two paragraphs, may be quoted without explicit permission provided that full credit, including (C) notice, is given to the source. 
The Impact of Early Investments in Urban School Systems in the United States

Ethan J. Schmick and Allison Shertzer

NBER Working Paper No. 25663

March 2019, Revised March 2020

JEL No. H72,I26,N32

\begin{abstract}
$\underline{\text { ABSTRACT }}$
Cities in the United States dramatically expanded spending on public education in the years following World War I, with the average urban school district increasing per pupil expenditures by over 70 percent between 1916 and 1924 . We provide the first evaluation of these historically unprecedented investments in public education by compiling a new dataset that links individuals to both the quality of the city school district they attended as a child and their adult outcomes. Using plausibly exogenous growth in school spending generated by anti-German sentiment after World War I, we find that school resources significantly increased educational attainment and wages later in life, particularly for the children of unskilled workers. Increases in expenditures can explain between 19 and 29 percent of the sizable increase in educational attainment of cohorts born between 1895 and 1915 .
\end{abstract}

Ethan J. Schmick

Washington \& Jefferson College

60 S. Lincoln St.

Washington, PA 15301

eschmick@washjeff.edu

Allison Shertzer

Department of Economics

University of Pittsburgh

4901 WW Posvar Hall

230 South Bouquet Street

Pittsburgh, PA 15260

and NBER

shertzer@pitt.edu 
"Every great war in which the United States has played a part has been followed by educational developments of supreme national importance...Although the United States was engaged in the World War less than two years, the effects upon education resulting from this brief period of warfare will perhaps prove to be as far-reaching and as important as those growing out of any previous war...Undoubtedly the World War was the most important factor in awakening the American public to the inadequacy of its educational provisions and in arousing the States to vigorous efforts to improve educational conditions."

- Fletcher Harper Swift, Biennial Survey of Education 1920-1922, Volume 1, pp. 1-2.

\section{Introduction}

The question of how much to invest in education - and the returns to those investments has attracted a great deal of attention in economics, particularly in light of the substantial increases in spending occurring nationwide since the 1960s (Coleman et al., 1966; Card and Krueger, 1992; Betts, 1996; Hanushek, 1986, 1996). Publicly funded education has long been viewed as the most important policy tool for improving the future labor market outcomes of children, particularly youth from disadvantaged backgrounds. Accordingly, concerns about disparities in access to educational resources have motivated a complex and evolving system of transfers from the federal and state governments to local districts. ${ }^{1}$ However, for much of American history, local governments assumed the bulk of the responsibility for financing their own school systems.

This paper studies the impact of the unprecedented investments in public education made by city school districts in the aftermath of World War I and provides the first nationwide, districtlevel analysis of spending on education in early twentieth-century America. The city-district level is the finest geographic unit for which there are comprehensive surviving records from this period. We digitized reports of education published biennially for city school districts from 1900 to 1930

\footnotetext{
${ }^{1}$ For instance, the state share of public elementary and secondary school revenues nationally grew from 30 percent to over 50 percent between 1940 and 1990 ("Revenues and Expenditures for Public Elementary and Secondary School Districts" (Fiscal Year 2010), National Center for Education Statistics: https://nces.ed.gov/pubs2013/2013307.pdf). Federal outlays increased significantly beginning in the 1960s.
} 
for major cities in the U.S. The top graph in Figure 1 displays the trend in real expenditures per pupil in our sample of cities separately by census region. The growth in educational spending by cities after the United States entered World War I marked a significant departure from nineteenth century levels. On the eve of the United States entering World War I, real expenditures per pupil were about $\$ 82$ (in 1930 dollars). However, between 1916 and 1924, expenditures ballooned to $\$ 142$ per pupil, a 73 percent increase. Such a rapid increase in real expenditures per pupil would not occur again until the 1960s.

This paper leverages several newly digitized data sources to examine the impacts of these investments. We constructed measures of student exposure to higher spending on education using the Report of the Commissioner of Education (1900-1916) and the Biennial Survey of Education (1918-1930). To obtain adult outcomes for students educated in urban schools during these decades, we matched school-age individuals from the 1900,1910, 1920, and 1930 complete count censuses to the 1940 complete count census. Because the 1940 census only contains information on state of birth, linking individuals is essential to match adults in 1940 to the local level of school resources they experienced as children. An advantage of our approach is that we can investigate the potentially heterogeneous returns to educational resources based on childhood socioeconomic status, a task that is generally not possible with retrospective analyses.

The trends apparent in Figure 1 suggests that World War I played a critical role in this early major investment in public education in American cities. To our knowledge, the returns to this war-driven expansion of school resources have not previously been studied in economics. ${ }^{2}$

\footnotetext{
${ }^{2}$ While the economic consequences of urban school spending have been largely unexplored for the early twentieth century, a large literature has investigated the impacts of educational investments made in the ensuing decades. A significant number of papers, particularly those using test scores as outcomes and a difference-in-difference approach, echo the findings of the Coleman Report and find little evidence of a relationship between school inputs and student outcomes. On the other hand, a literature using state-level aggregated education metrics has largely found positive returns to mid-twentieth century school expenditures (Morgan and Sirageldin, 1968; Akin and Garfinkel, 1977; Card and Krueger, 1992).
} 
However, historians have studied the expansion of public education over the course of the early twentieth century. Progressive Era reformers were motivated by the need to prepare foreign youth for the American labor market, and voters largely supported investments in education (Goldin, 2001). Progressive Era education crusaders particularly supported higher school spending in "foreign and congested" neighborhoods as well as improved instruction in matters of citizenship, character formation, and vocational education that emphasized the hierarchical nature of early twentieth century work (Amsterdam, 2016).

Our empirical strategy relies on the observation that post-World War I expansions in school resources were in part a response to immigrants from enemy nations who had already settled in the United States. World War I abruptly downgraded the status of ethnic Germans living in the Unites States (Moser, 2012). Anti-German hysteria exploded across many facets of American life, from outright violence to politically divisive Americanization laws, some of which outright forbid instruction in the German language (Lleras-Muney and Shertzer, 2015; Fouka, 2019). City governments reacted with panic to large populations of German descent and undertook efforts to assimilate the children of enemy aliens through public schooling, along with expanded city school budgets (Ross, 1994). We argue that anti-German panic can be used to construct an instrument for school resources.

The intuition for our approach borrows from the literature on the impact of post-1960 increases in public school resources, which has found that estimates depend crucially on whether expenditures are exogenously determined (Jackson et al., 2016; Lafortune et al., 2018; Lavy, 2015). The narrative history suggests that city school system administrators during the Progressive Era responded to deteriorating student outcomes by increasing spending. A naïve panel estimation of the returns to such endogenously determined school resources would be biased towards zero. 
We develop an instrument for increases in school spending that is instead related to anti-German sentiment as proxied by exposure to post-World War I school spending in cities that had differing levels of German settlement prior to the conflict. We show this instrument is both predictive of spending on education after World War I and robust to a range of tests for violations of the exclusion restriction. Importantly for our identification strategy, it is not the case that attainment or wages were trending differentially across cohorts in cities with different German shares.

We find no evidence of a positive return to educational spending associated with endogenous increases in resources for either attainment or wages, consistent with reactionary increases in school resources by early twentieth century city school boards. However, utilizing variation in spending arising from pre-WWI German settlement yields economically significant estimates. A 10 percent increase in educational expenditures per pupil across all eight mandatory years of education led to an increase in educational attainment of about one month. We also find that a 10 percent increase in expenditures per pupil increased the probability of completing eighth grade by about 2 percentage points and increased wages in adulthood by about 1.5 percent.

We also find strikingly different results by childhood socioeconomic status. In particular, the effects on eighth grade completion and wages in adulthood are driven by the children of bluecollar workers. The eighth-grade completion effect is five times larger for these children relative to the children of white-collar workers. Increased educational resources related to anti-German sentiment appear to have primarily benefited the children of lower socioeconomic status families, regardless of nativity. Overall, higher spending on public education can explain between 19 and 29 percent of the sizable increase in attainment of cohorts born between 1895 and 1915 .

Our findings shed new light on the long-running debate on returns to schooling resources in the United States. We find robust evidence that investments in public schools led to higher 
educational attainment and adult wages for less-advantaged children, providing an urban companion to recent papers examining the return to school spending in rural and Southern counties in the early twentieth century. For instance, Aaronson and Mazumder (2011) find large impacts of Rosenwald schools on the achievement of African American children. Carruthers and Wanamaker (2017) find that public school expenditures in counties in the Jim Crow South had large impacts on wages, particularly for African American children. Finally, Card et al. (2018) find evidence linking public school quality with upward educational mobility.

World War I was a watershed in the provision of public education in the United States, yet we find little evidence that even large investments that primarily benefited less-advantaged children were effective in closing the urban educational attainment gap that existed between the children of high and low-skilled fathers, which remained constant at about one year throughout the early twentieth century. However, it is possible that educational investments made by cities allowed the "Great Compression" of wage inequality to occur later in the twentieth century by helping the children of unskilled workers at least keep up with their more advantaged peers (Goldin and Margo, 1992; Collins and Niemesh, 2019). An ancillary result of our paper is that early state efforts to prop up local school finances crowded out local spending on education. Our findings thus also relate to the history of transfers intended to equalize access to school resources demonstrating that the gains in our context were generated by cities themselves - however indirectly - rather than through financing schemes undertaken by the state or federal government (Cascio et al., 2013). 


\section{Background and Historical Context}

\section{2.a. Public education around World War I}

The early twentieth century saw rapid population growth in cities, fueled largely by immigration from Europe. Foreign-born workers were seen as resistant to assimilation into American society, and, troubling for city leaders, susceptible to organized labor movements. ${ }^{3}$ The concerns about unassimilated immigrants heightened as the United States entered World War I, and reformers called for investments in public education to help immigrant youth adopt American values for the sake of national solidarity. A quote from an introduction to one edition of the Biennial Survey of Education illustrates why the conflict generated pressure to improve education across the county:

"It was not until American Army officers found it necessary to have their orders shouted to American privates in three, four-yes, and even five-languages that America awoke, awoke to the fact that in a country whose laws, whose very ideals were written in English, thousands upon thousands of adult citizens could not read a single word of the language of their adopted country."4

The German population in U.S. cities was substantial and a source of concern for elected leaders. On April 6, 1917, President Woodrow Wilson gave an inflammatory declaration of war speech in which he warned at length of the dangers of enemy aliens, which he defined to be male immigrants from Germany over the age of thirteen. ${ }^{5}$ Meanwhile, the Justice Department attempted to compile a list of all male and female German immigrants and arrested over 4,000 of them on

\footnotetext{
${ }^{3}$ Annual Report of the Detroit Public Schools, 1920.

${ }^{4}$ Biennial Survey of Education 1920-1922, p. 2.

${ }^{5}$ Wilson spent 19 of the 25 paragraphs of his declaration of war speaking about enemy aliens and he warned them to "preserve the peace towards the United States and to refrain from crime against public safety." He even set limits on enemy aliens' proximity to government buildings: "An alien enemy shall not approach or be found within one-half of a mile of any Federal or State fort, camp, arsenal, aircraft station, Government or naval vessel, navy yard, factory, or workshop for the manufacture of munitions of war."
} 
charges of espionage (Yockelson, 1998). Anti-German sentiment reached its peak in April of 1918 when Robert Prager, a German immigrant, was lynched by a mob in Collinsville, Illinois. ${ }^{6}$

Education was viewed as the foremost policy tool for controlling the Teutonic threat by inculcating a sense of loyalty to America in individuals of German descent. City leaders hoped that children would introduce their parents to the English language and American values they learned about in school (Schlossman, 1983). Accordingly, school curricula were reformed to include matters of citizenship and civic duty (Land, 2002). However, the literature has generally not found that Americanization education policies improved assimilation-related outcomes for foreign-born youth (Lleras-Muney and Shertzer, 2015; Fouka, 2019). We thus take the view that investments in public education after World War I improved the school environment for children in general without having much of a direct assimilation effect on immigrant children. Our results are consistent with this historical interpretation; effects of school spending on immigrants and the native born are generally similar, and our results are not driven by German youth.

Our finding that cities with larger German populations increased spending on public education by greater amounts is not surprising when viewed in the broader historical context. Education reformers found the German threat narrative to be a useful tool for increasing public support for the ballooning school budgets that were proposed in cities across the country in the aftermath of the conflict. In the city of Chicago, a former member of the Board of Education proposed the enactment of a criminal statute compelling school attendance for any American between the ages of 16 and 45 who could not read and write in the summer of 1918, just a few months before the Armistice was signed (Ross, 1994). Such thinly veiled attempts to demonize

\footnotetext{
${ }^{6}$ See Hickey (1969) for a detailed historical explanation of this event. Although extreme, this lynching was far from the only instance of mob violence toward German immigrants during World War I. There were numerous other instances of mob violence in Kansas and Illinois and a plaque in Cincinnati still commemorates the "Anti-German Hysteria" that swept the city in 1917 and 1918 (Juhnke, 1975).
} 
unassimilated immigrants, at the moment of peak anti-German sentiment, likely assisted with the passage of new education budgets even if few such proposals became law. With these increased resources, city school reformers could tackle goals such as increasing basic literacy by improving the quality of schools and the duration of time poor pupils spent attending them. ${ }^{7}$ We provide empirical support for the relationship between German immigration and increases in school resources in Section 4.b.

\section{2.b. The role of the state in the provision of public education}

During the early twentieth century state governments limited their involvement in public education to two areas. First, state legislatures passed compulsory schooling laws (CSLs) and child labor laws intended to keep children in school through eighth grade (or longer if they were not in the labor force). Studies investigating the impacts of these laws have found mixed results but generally agree that state legislation was not the primary driver of the increase in educational attainment in the early twentieth century. ${ }^{8}$

The second source of state involvement was in providing transfers to municipalities to support education. Beginning in the middle of the nineteenth century, state governments began to recognize that some municipalities and counties were too poor to provide a quality public education to children living within their borders. The typical policy response was to pass a law

\footnotetext{
${ }^{7}$ World War I also revealed the extent of illiteracy among draft-aged men; a 1921 government report suggested that perhaps a quarter of men in wartime Army camps could not read or write in English. This report, edited by Robert Yerkes, is entitled Psychological Examining in the United States Army. Table 279 of this report shows that about 25 percent of men were administered the "beta" intelligence tests, which "was developed primarily for men who could not read and write English and was used for these men in place of the alpha examination, which presupposes English literacy" (p. 743; Yerkes, 1921).

${ }^{8}$ Landes and Solmon (1972) find no effect of compulsory schooling laws (CSLs) while Eisenberg (1988) finds modest effects on school attendance. Margo and Finegan (1996) find that CSLs significantly increased attendance in states that coupled a CSL with comprehensive child labor laws. Lleras-Muney (2002) finds that legally requiring children to attend one more year of school increased educational attainment by 5 percent. Clay et al. (2016) use CSLs to demonstrate that the returns to schooling were highest for the lowest quantiles of the 1940 wage distribution.
} 
requiring all localities to provide at least universal primary school access. The states would then provide a "flat grant", or a lump sum of money, to each locality to help finance the operation of those primary schools. Flat grants were distributed to rich and poor districts alike. As the cost of education rose in the early twentieth century, states switched their funding formulas to a per classroom, per teacher, or even per school-age pupil flat grant (Odden and Picus 2004).

It was not until the Strayer and Haig (1923) report, Financing Education in the State of New York, that states began to switch from flat grant financing schemes to "foundation" programs. These programs set a minimum foundation level of revenue per pupil that a district should collect in taxes. If poorer districts could not meet this minimum, then the state made up the difference. Such equalization schemes gained traction during the Great Depression and were widespread by 1940. Figure 2 shows the percent of city school revenues that came from the state government in 385 major cities during our study period. In 1930, city governments were contributing about 85 percent of the revenue for schools, while states were contributing just over 10 percent. ${ }^{9}$

The impact of early grant programs on local school finances has gone largely unexplored in economics. Of particular interest is the question of whether policy changes that increased funds from the state can serve as an instrumental variable for school resources in the spirit of the courtordered reforms used by Jackson et al. (2016). We obtained information on which states passed laws mandating major increases in grants from the state to local districts immediately following World War I from the Biennial Survey of Education. ${ }^{10}$ In some cases, state aid was doubled. Figure 3 illustrates the impacts of these policy changes. Panel A shows the increase in state revenues per

\footnotetext{
${ }^{9}$ Some states, such as Missouri, depended on counties as the primary unit of organization to support education.

${ }^{10}$ The 1920-1922 Biennial Survey of Education reports that "Among the States which since the close of the World War provided for greatly increased school revenue to be furnished by the State are Arizona, California, Georgia, Iowa, Louisiana, Massachusetts, New York, North Carolina, Pennsylvania, South Carolina, Texas, Utah, Washington, and West Virginia" (p. 16).
} 
pupil in cities located in states that modified their grant law. However, city revenues appear to have dropped by an equivalent amount, and Panel B shows that expenditures per pupil were virtually unchanged after the laws came into force.

These figures suggest that early grant programs crowded out local spending on education. We confirm these findings by running a simple difference-in-differences regression on our baseline sample of cities where we include dummies for the post-WWI period and the passing of a state law increasing grant aid, as well as the interaction of these factors. We report the results in Table 1. In states that passed a grant law after World War I, city school districts received an additional $\$ 4.53$ per pupil from the state government (column 1). However, the revenues a school received from the city decreased by about $\$ 4.82$, leaving overall expenditures per student unchanged (columns 2 and 3, respectively). It thus appears that increased state aid to schools after World War I crowded out local investments in education almost one for one. We therefore develop a novel instrument for changes in educational resources using anti-German sentiment, which is discussed in Section 4.

\section{Data}

\section{3.a. City school resource data}

We used the Report of the Commissioner of Education (1900-1916) and the Biennial Survey of Education (1918-1930) to construct a new city-level dataset on public school resources. We collected the available data on school resources for every other academic year, beginning with the 1899-1900 academic year. ${ }^{11}$ The reports contain information on expenditures on teachers and

\footnotetext{
${ }^{11}$ We have data for academic years beginning with an odd number from 1899-1900 through 1929-1930 except for the academic year 1915-1916. We could not locate a report for the 1915-1916 academic year so we collected data for the 1914-1915 academic year instead.
} 
supervisors, expenditures on capital, other expenditures, average daily attendance in public schools, the number of public school teachers, and the revenues that city school districts received from city, county, and state governments. These data allow us to compute total expenditures per pupil, which we define as the sum of expenditures on teachers, supervisors, capital, and other expenditures all divided by the average daily attendance in a school. For our analysis, we form a panel of 385 of the largest cities in the United States during the early twentieth century. ${ }^{12}$

To provide a more complete picture of the evolution of school resources in the early twentieth century we graph time series of real expenditures per pupil and the pupil-teacher ratio in Figure 1. Panel A of Figure 1 shows real expenditures per pupil, which were fairly flat from 1900 to 1920 . It is only after 1920 that large real increases are evident. Average real expenditures per pupil increased from $\$ 78$ in 1920 to $\$ 142$ in 1924 , an 82 percent increase. Panel B graphs the pupil-teacher ratio, which decreased steadily from 1900 to about 1920 before levelling off. Figure 1 suggests that increased expenditures after WWI were not simply a matter of smaller class sizes.

To explore this idea further, Figure 4 breaks the time series of real expenditures per pupil into three main categories of expenditures: expenditures on teachers and supervisors, operations, and capital. The overall trend shows decreasing percentages spent on teachers and supervisors and increasing percentages spent on capital and operations. Expenditures on teachers and supervisors made up about 60 percent of total expenditures in 1900, but this category dropped to around 50 percent by 1930. Expenditures on capital and operations each made up less than 20 percent in 1900, but had increased to around 25 percent by 1930, reflecting the burst of new school

\footnotetext{
${ }^{12}$ For academic years where data is missing for one of our cities it is interpolated by using the two adjacent academic years. The population of cities in the sample exhibits a long right tail, with a few cities having very large populations. New York City is an extreme outlier with a population of 3,437,202 in 1900, which is over twice the size of Chicago (the next largest city). The strength of our first-stage estimates are slightly sensitive to the inclusion of New York City, and accordingly we chose to drop this city from our analysis. The cities in our sample are shown in Appendix Figure A.I.
} 
construction. Panel A of Table 2 displays decadal summary statistics for the 385 city school systems in our sample.

\section{3.b. A linked sample}

To measure student outcomes, we construct a dataset of individuals linked from the 1900, 1910, 1920, and 1930 complete count censuses to the 1940 complete count census (Ruggles et al., 2018). Linking individuals is necessary to match adults in 1940 to the local level of school resources they experienced as children. We begin our linking procedure by restricting the 1900,1910, 1920, and 1930 censuses to males, who were 6 to 15 years of age when the census occurred and were living in one of the 385 cities for which we have school resource data.

We employ the linking procedure used by Abramitzky et al. (2012), Abramitzky et al. (2014), and many others (i.e. the ABE linking algorithm). We begin by adjusting first names for common nicknames and then standardize each first and surname using the NYSIIS algorithm, which transforms a word into a phonetic code. We then restrict our sample to individuals who are unique by NYSIIS first name, NYSIIS surname, birthplace, and birth year. For each individual in the $1900,1910,1920$, and 1930 census we search for records in the 1940 census that match exactly on NYSIIS first name, NYSIIS surname, birthplace, and birth year. If we find a unique match, then we declare this observation to be a match. If we find multiple matches, then the observation is discarded. If we do not find a unique match then we continue to search for individuals who match exactly on NYSIIS first name, NYSIIS surname, and birth place, but we now allow birth year to differ by up to one year (e.g. if an individual in the 1910 census reports a birth year of 1902 we will search for individuals in the 1940 census with a birth year of 1901 and 1903). If no unique 
match is found we continue to search for individuals who match exactly on NYSIIS first name, NYSIIS surname, and birthplace, but we now allow birth year to differ by up to two years.

The results from this linking procedure are displayed in Appendix Table A.I. From the 1900 complete count census we searched for 1,948,639 individuals and were able to find 585,386 of them in the 1940 census (a 30 percent link rate). As shown in Appendix Table A.I, we find that our link rates for 1910, 1920, and 1930 are 33, 35, and 39 percent, respectively. We also examine the representativeness of our linked sample. Even though statistically significant differences exist along numerous dimensions between our final linked sample and the original sample, these differences are mostly small in magnitude. We show the robustness of our main results to alternate matching procedures in Section 5.b.

One area where we do find larger differences between the linked and the original samples is that children from more advantaged families are more likely to be linked. For example, individuals in our linked sample are usually about 4 percentage points more likely to live in a dwelling that is owned, as opposed to rented. In addition, the parents of individuals in our linked sample have a slightly higher literacy rate and the fathers have slightly higher occupational income scores. We address these differences by splitting the sample based on whether the father is high or low socioeconomic status in some specifications. We define a high socioeconomic father as a father whose occupation was a professional, manager, proprietor, clerk, or salesman.

Before constructing weekly wages for individuals we follow Acemoglu and Angrist (2000) by censoring annual earnings at the 98th percentile and assigning values above the 98th percentile with 1.5 times the 98th percentile value. After censoring we construct weekly wages by dividing annual earnings in 1939 by the number of weeks worked in 1939. Finally, we discard the top and bottom one percentile of weekly wage earners and the top and bottom two percentiles of years of 
education. ${ }^{13}$ Panel B of Table 2 displays summary statistics of outcome variables for our sample of linked men. For an individual to be included in these summary statistics (and in our preferred specification), he must be an employee and report a weekly wage. Consequently, self-employed men and business owners are excluded from our analysis.

\section{Empirical strategy}

\section{4.a. Panel Estimation using OLS}

The objective of our empirical work is to identify the causal effect of early twentieth century increases in school resources on adult outcomes. We begin with a naïve estimation of the effect in a panel framework using the following equation:

$$
[\text { outcome }]_{i e c}=\boldsymbol{X}^{\prime}{ }_{i e c} \boldsymbol{\delta}+\boldsymbol{Y}_{e c}^{\prime} \boldsymbol{\beta}+\gamma_{c}+\gamma_{e}+\varphi[\ln \text { expenditures per pupil }]_{e c}+\tau_{i e c}
$$

In equation (1), $i$ indexes individuals, $e$ indexes city-of-education, and $c$ indexes cohorts. [outcome $]_{i e c}$ is one of five adult outcomes: (1) educational attainment, (2) the probability of completing 8th grade, (3) the probability of graduating from high school, (4) weekly wages, and (5) the probability of working a white-collar job. We restrict the sample to white men born between 1894 and 1916 because our school resource data cover the 1900 to 1930 period and we, therefore, can only compute a complete average during mandatory school-age years for these individuals. ${ }^{14}$

\footnotetext{
${ }^{13}$ Appendix Figure A.II displays a histogram of educational attainment in our sample. Trimming on the $2^{\text {nd }}$ and $98^{\text {th }}$ percentiles means that we drop individuals with fewer than three or more than sixteen years of schooling.

${ }^{14}$ In addition, we face the issue that we are assigning school resources based on year of birth, but we allowed year of birth to differ by up to two years when performing the linking. We resolve any discrepancies by assigning school quality based on the birth year that is reported when the individual was a child (i.e. birth year reported in the 1900, 1910,1920 , or 1930 census). We also test the robustness of our main results using just individuals that match exactly on birth year and find little difference.
} 
We trim on the top and bottom two percentiles of years of education and one percentile of wage earnings.

The vector $\boldsymbol{X}_{\text {iec }}^{\prime}$ contains individual-level characteristics including: mother's literacy (three dummy variables: mother literate, mother illiterate, and mother not present), father's literacy (three dummy variables: father literate, father illiterate, and father not present), mother's occupation (dummies), and father's occupation (dummies). The vector $\boldsymbol{Y}_{\boldsymbol{e c}}^{\prime}$ are city-of-education by cohort level controls. This vector contains a series of variables for the average percentage of each county's working population employed in various professions during each cohort's mandatory school age years. In particular, we control for the percent of a county's working population employed as a professional, craftsmen, operator, service worker, laborer, or farmer. To calculate these variables, we divided the number of individual's reporting a particular profession by the total number of individuals reporting any profession in that county using the 1900-1930 complete count censuses from the Integrated Public Use Microdata Series (IPUMS; Ruggles et al. 2018). ${ }^{15}$ These percentages are then linearly interpolated between census years. $\gamma_{c}$ is a cohort fixed effect and $\gamma_{e}$ is a city-of-education fixed effect. For our main treatment variable, we construct a measure of a student's exposure to school resources, [ln expenditures per pupil $]_{e c}$, which is the log of average expenditures per pupil (in real 1930 dollars) during expected school-age years (ages 6-14 during our time period) for individuals in cohort $c$ who were educated in city $e$. Finally, $\tau_{\text {iec }}$ is a stochastic error term and we cluster standard errors at the city-of-education level.

Our primary identification concern is that the OLS panel estimation may be biased. If cities made dynamic investment decisions and increased spending by more when schooling outcomes were deteriorating, estimated impacts of school resources would likely be biased towards zero.

\footnotetext{
${ }^{15}$ We use the county, not the city, to construct this measure because the IPUMS data do not identify all of the cities in our sample. We map the cities in our sample to the county they were located in during the 1910 census.
} 
The narrative history certainly suggests that reformers lobbied for larger school budgets in response to the poor performance of "foreign elements" in the school system during a period of generally high immigration before 1924. We next discuss our instrumental variables approach, which aims to isolate variation in school resources uncorrelated with trends in student outcomes.

\section{4.b. Instrumental variables approach using anti-German sentiment}

Our instrumental variable approach exploits variation in educational spending that arose as a result of anti-German sentiment as opposed of concerns about schooling outcomes. Specifically, we construct a measure of exposure to years of education after World War I interacted with the share of the population in a city that is of German descent. Our approach shares some similarities to Acemoglu et al. (2004), who use county German share to obtain variation in World War II mobilization rates uncorrelated with economic conditions. In this section we show that our instrument is both predictive of future increases in educational spending and that German share is driving increases and not general immigrant levels. Finally, we provide a set of checks of the exclusion restriction, including showing that cities with different German shares were not on different trajectories of wages or educational attainment prior to WWI.

We visualize the basic variation underlying our approach in Figure 5. Specifically, we subdivide our sample of cities by median German population share and show trends in spending per pupil. Prior to World War I, cities with higher German shares spent more on education than cities with lower German shares. The level differences arise largely as a function of geography, with German immigrants having settled predominantly in the large, industrial cities of the Midwest and Northeast and having largely avoided the South (see Panel A of Table 3). The gap in expenditures per pupil between above and below median German share cities remained fairly 
constant in the decade leading up to the war at about 17 percent. However, after 1918 the gap between expenditures per pupil in high and low German cities began to widen. By 1924, the gap had reached 34 percent, double the level of the gap in $1918 .^{16}$

In order for the German share of the population interacted with exposure to years of education after World War I to be suitable as an instrument for educational expenditures, it must be the case that the presence of Germans specifically prompted increased spending on education around the time of the war, when fears of enemy aliens peaked. Panel A of Table 4 confirms this notion. Column (1) of Table 4 shows that cities with above median German shares of the population in 1910 increased expenditures per pupil after World War I by 4 percent relative to cities with low German shares. Column (2) uses the log of a continuous measure of the German share of the population. Finally, columns (3) and (4) of Table 4 show that having a high German population, not a high foreign-born population more generally, is what led to the divergence in expenditures per pupil using both dichotomous and continuous measures of non-English-speaking, non-German immigrants.

One concern regarding the validity of our identification strategy is whether cities with high German shares of the population were on systematically different trajectories from cities with lower German shares of the population. For example, if German immigrants had a preference to settle in cities with growing tax bases and increasing expenditures of public schools this would invalidate our argument that city schools responded to the German share of the population by increasing expenditures after World War I. We provide evidence that German immigrants were not simply clustered in cities with better tax bases in Panel B of Table 4. Specifically, we run a

\footnotetext{
${ }^{16}$ Real expenditures per pupil in 1908 in high German share cities was $\$ 85$ and it was $\$ 70.86$ in low German share cities. In 1918, expenditures per pupil were $\$ 75.62$ in high German share cities and $\$ 64.38$ in low German share cities. Finally, in 1924, expenditures per pupil were \$154.29 is high German share cities and \$115.29 in low German share cities.
} 
series of regressions on 100 cities for which we obtained non-educational public expenditure data. ${ }^{17}$ These regressions, shown in Panel B of Table 4, demonstrate that the German share of a city's population does not appear to have significantly impacted public expenditures on fire, police, and sewer services after World War I. If anything, such cities spent less on these other public goods. These results strongly suggest that German share is not simply a proxy for a growing postWorld War I tax base.

A related concern is that cities or regions with more Germans were on different trends on unobservable dimensions that would somehow have led to differing evolutions of educational attainment or wages in the absence of increased educational spending. For instance, it could be the case that areas with more Germans were shifting out of manufacturing and into services more rapidly. To explore this idea, Panels B through D of Table 3 examine demographic and economic characteristics of cities based on the German share of the population. Panel B shows that cities with high German shares had larger populations and a lower percent black, which is consistent with few Germans settling in the South. Panel C shows that while there are some significant differences in the industrial composition of high and low German cities, these differences are generally small in magnitude (less than three percentage points). Importantly for our identification, Panel D shows that there are no differential trends in the growth of industries in high versus low German cities between 1910 and 1920. We nonetheless include controls for industrial structure in our baseline specification (see Section 4.a). We also show our main results are robust to the inclusion of regional trends in Section 5.a.

\footnotetext{
${ }^{17}$ Spending on fire, police, and sewer services from the Statistics of Cities were provided by Elyce Rotella and Louis Cain.
} 
Our instrument for educational expenditures uses exposure to a high-German share of the population prior to World War I to predict increases in expenditures per pupil after the war. We therefore estimate the following system of equations using two-stage least squares (2SLS):

$$
\begin{aligned}
& {[\ln \text { expendıtures per pupıl }]_{\text {lec }}} \\
& =\boldsymbol{X}^{\prime}{ }_{i e c} \boldsymbol{\delta}+\boldsymbol{Y}_{\boldsymbol{e c}}^{\prime} \boldsymbol{\beta}+\gamma_{c}+\gamma_{e}+\varphi[\text { exposure }]_{c} \\
& \times\left[\text { German share }_{1910}\right]_{e}+\tau_{\text {iec }} \\
& {[\text { outcome }]_{i e c}=\boldsymbol{X}^{\prime}{ }_{i e c} \boldsymbol{\beta}+\boldsymbol{Y}_{\text {ec }}^{\prime} \boldsymbol{\rho}+\theta_{c}+\theta_{e}} \\
& +\sigma[\ln \text { expenditures per pupll }]_{l e c}+\varepsilon_{i e c}
\end{aligned}
$$

In equations (2) and (3), $\gamma_{c}$ are cohort fixed effects, $\gamma_{e}$ are city-of-education fixed effects, $\boldsymbol{X}^{\prime}{ }_{\text {iec }}$ are individuals level control variables, and $\boldsymbol{Y}_{\boldsymbol{e} \text { c }}^{\prime}$ are city-of-education by cohort level controls. $[\text { exposure }]_{c}$ is cohort c's exposure to years of schooling after the United States entered World War I in 1917. Therefore, [exposure $]_{c}$ is zero for individuals born before 1905, one for individuals born in 1905, two for individuals born in 1906, and takes a maximum value of eight for individuals born after 1911, since all eight years of mandatory schooling would have occurred after the United States entered World War I. Finally, [German share $\left.{ }_{1910}\right]_{e}$ is the German share of the population in the 1910 census for city-of-education $e$.

A recent literature has highlighted the importance of the assumptions made about the trends in outcomes absent treatment and the stability in treatment underlying empirical approaches such as ours (for instance, see De Chaisemartin and D'HaultfEuille, 2017). In our context, we require that cities with high German shares of their population did not have differential trends in our 
outcome variables prior to the beginning of World War I. To test for these differential trends, we estimate the following equation:

$$
\begin{aligned}
{[\text { outcome }]_{i e c} } & =\boldsymbol{X}^{\prime}{ }_{i e c} \boldsymbol{\delta}+\gamma_{c}+\gamma_{e} \\
& +\varphi_{c} \sum_{c=1895}^{1916} \gamma_{c} \times[\text { High German share }=1]_{e}+\tau_{i e c}
\end{aligned}
$$

This equation is similar to equation (1), but we replace expenditures per pupil with a series of cohort dummy variables (omitting 1894) interacted with a dummy variable if the individual was educated in a high-German-share city. We wish to demonstrate that individuals who were living in high-German-share cities and were completely educated prior to World War I had similar outcomes to individuals living in low-German-share cities.

We plot the coefficients $\varphi_{c}$ in Figure 6. Panel A shows the coefficients when educational attainment is the dependent variable. There is no significant difference in educational attainment for individuals living in high German cities who were completely educated prior to World War I (the 1895-1899 birth cohorts). We begin to see an upward trend in educational attainment for individuals educated in high-German cities with the 1900 birth cohort. The 1900-1904 birth cohorts could have been in high school during and shortly after World War I, so individuals from high-German-share cities would have experienced some of the rapid, war-induced increase in expenditures. Finally, because compulsory schooling laws mandated most children to stay in school until at least the age of 14, the 1905 birth cohort and all later cohorts were definitely exposed to some post-World War I education. Accordingly, the upward trend that started in 1900 is more pronounced for these cohorts. Panel B of Figure 6 plots the coefficient estimates when $\log$ of 
weekly wage is the dependent variable. Again, we see no upward trend prior to the 1900 birth cohort.

We also illustrate the trend in school spending by German share in Appendix Figure A.III. Estimated differences in average expenditures per student are essentially flat for cohorts born between 1897 and 1905, after which high-German cities begin to spend more. We interpret these figures as rejecting the notion that individuals from high German cities had differential trends in either key inputs or outcomes prior to the post-World War I increase in expenditures.

\section{Results}

\section{5.a. Main results}

We begin our analysis by estimating equations (1)-(3) for our five outcomes of interest. Panel A of the Table 5 presents the baseline panel regression estimates. Consistent with the expectation that the naïve OLS estimation would be biased downwards, nearly all of the panel estimates are close to zero. Panel B of Table 5 reports the second-stage from our 2SLS approach. Column (1) shows that a 10 percent increase in expenditures per pupil during mandatory school-age years increased educational attainment by 0.17 school years. For a typical 180-day school year, this effect translates into approximately 31 days of additional school. In columns (2) and (3) we find that a 10 percent increase in expenditures per pupil increased both the probability of eighth grade completion and high school graduation by about 2 percentage points. Column (4) shows that a 10 percent increase in expenditures per pupil led to a 1.5 percent increase in adult wages. Finally, we do not find any significant effect of educational expenditures per pupil on the probability of whitecollar work with the important caveat that our sample excludes self-employed workers and business owners. 
We next explore the robustness of these results to the inclusion of regional time trends to address the concern that areas with more Germans were evolving along unobservable dimensions in terms of wages or educational attainment. Table 6 reports the results of the baseline specification with the addition of four census region time trends, which for instance allow the "German Triangle" in the Midwest to have a different trend relative to the Northeast. Our estimates for attainment, eighth-grade completion, and wages are similar but slightly attenuated in the case of attainment. The estimated effect on high school completion drops by more than half and loses significance. We conclude that the German share instrument may be picking up some regional trends in high school completion. However, it appears unlikely that trends in attainment at lower rungs of the educational ladder or in wages are being driven by general trends across region that are correlated with German share.

To put these results into context, the average student in our sample saw expenditures per pupil increase by 41 percent over his eight mandatory years of schooling. This increase would translate into between .58 and .38 years of additional educational attainment, depending on the inclusion of regional trends, using the estimates from Tables 5 and 6. During our study period educational attainment increased by two years from the 1895 cohort to the 1915 cohort, meaning that increased expenditures per pupil can account for between 19 and 29 percent of the increase in educational attainment. The same average increase in expenditures translated into wage increases of 4.2 to 5.1 percent.

Our first stage F-statistic in all the 2SLS regressions is about 10 to 12 , indicating a sufficiently strong first stage. In Appendix Table A.II., we perform a robustness check where we drop individuals educated in cities whose populations were over 250,000 in 1900. The 2SLS estimates are displayed in panel B and our first stage is even stronger for this subsample, with an 
F-statistic of over 33, and the coefficient estimates remain unchanged. Only 17 cities in our sample have populations over the 250,000 , indicating that our effects are not simply being driven by the extremely large cities. In fact, it could be the case that our instrument has more power in this subsample if immigrant populations were more noticeable in smaller cities.

Individuals born after 1910 would be under the age of 30 in 1940 and may not have achieved their full earnings potential. We explore the robustness of our 2SLS results to an age restriction in Appendix Table A.III. Panel A reproduces our baseline 2SLS results, while Panel B restricts the analysis to just individuals from the 1894-1910 birth cohorts. We find that our results are generally robust when restricting the sample to older cohorts that are more likely to be near their permanent income. Unsurprisingly, the impact of expenditures per pupil on adult wages becomes larger and more significant when examining these earlier cohorts.

\section{5.b. Alternative linking methods}

Our main results use a standard linking algorithm based on Abramitzky et al. (2012) and Abramitzky et al. (2014). However, Bailey et al. (2017) show that automated linking algorithms that use phonetically cleaned names can result in a large number of false positive matches (i.e. linking a child to the wrong adult). The rate of false positives in our sample would have to be systematically related to both the German share of a city's population and years in which a child was educated for our results to be confounded by the linking algorithm (e.g. many false positives for children educated in all places prior to World War I, but few false positives for children educated in high German share cities after World War I). While we believe this is unlikely, we, nevertheless, follow Abramitzky et al. (2019) and use three additional linking techniques to demonstrate the robustness of our results. 
First, we link individuals that match exactly on first name (not phonetically cleaned), last name (not phonetically cleaned), birthplace, and birth year. We re-estimate our main empirical results (Table 5) with this sample and display the results in Appendix Table A.IV. The results using only individuals that match exactly on name and birth year are almost identical to our main results. The second method links only individuals whose NYSIIS cleaned first and last name are unique within a five-year age band in both the initial census and the 1940 census. We, again, reestimate Table 5 using this unique name same and display the results in Appendix Table A.V. The results using the sample of individuals with unique names are almost identical to our main results. Finally, we link individuals that match exactly on name and birth year and that are unique within a five-year age band. The results using this method remain similar to our main results and are displayed in Appendix Table A.VI. It, therefore, appears unlikely that our results are sensitive to the choice of linking algorithm.

\section{5.c. Heterogeneous effects by socioeconomic status and nativity}

The early twentieth century was a time of significant inequality. An advantage of our approach is that we can assess the returns to school resources for children from different economic backgrounds. Table 7 shows our results broken down by the socioeconomic status of the individual's father. Panel A contains the results for children whose father had a blue-collar job, which we define as being a craftsman, operator, service worker, or laborer. Panel B shows the results for children whose father had a white-collar job, which we define as being a professional, manager, proprietor, clerk, or salesman. Each outcome is displayed in two columns, with the first column providing the OLS panel estimate and the second column containing the 2SLS estimate. 
We find that expenditures per pupil had large, positive, and significant effects on all outcomes for the children of low socioeconomic status, blue-collar fathers. In particular we find that a 10 percent increase in expenditures per pupil would have increased educational attainment by 0.2 school years (approximately 36 days), the probability of completing eighth grade by 2.2 percentage points, weekly wages by 1.6 percent, and the probability of white-collar employment by 0.6 percentage points. In comparison, we find that for the children of high socioeconomic status, white-collar fathers, expenditures per pupil only significantly increased educational attainment (and the probability of high school graduation, but we caution interpreting this latter effect as causal in light of our findings related to regional trends in Section 5.a). Despite the results being concentrated among the children of low socioeconomic status fathers, we do not find evidence that the gap in educational attainment between low and high socioeconomic students closed for the cohorts used in our sample. Figure 7 shows that the gap in educational attainment remained constant at over one year for all cohorts in our sample.

Why are the effects of increased school resources concentrated among the children of lower-skilled workers? One explanation is that the children of professionals were frequently enrolled in private schools and academies in the early twentieth century and, with high parental incomes, would have at least finished eighth grade regardless of the quality of public schooling in their city. We cannot test for the role of private schools directly; nonetheless, we believe that school quality would have had a larger scope for impact on children who could not afford private education. The difference in estimated effects across children of different socioeconomic factors also suggests that Progressive Era reformers followed through on their intentions to use increases in public money to improve educational outcomes for working class youth. 
Many of the lower-status workers and their children were foreign born. We close by considering differential impacts by nativity. This question is of particular interest since our instrument uses variation in school resources related to anti-German sentiment. We subdivide our sample by nativity and rerun our analysis in Appendix Table A.VII. Panel A shows the results for the native-born population, while Panel B shows the results for the immigrant population. We find that the effect of increased expenditures on educational attainment and high school completion largely accrued to native-born individuals. We also find that the effects of increased expenditures on eighth grade completion and adult wages were similar across the two groups. Immigration significantly declined during World War I and after the Emergency Quota Act was passed in 1921, so only a relatively small share of our sample ( 3 percent) was foreign born and school aged in the 1920s. Thus, although increases in school resources resulted from concerns about immigrant assimilation, the native-born (including second-generation immigrants) saw the broadest benefits although most effects are similar across the native and foreign born.

\section{Conclusion}

This paper documented that World War I was a pivotal moment in educational spending in American history. In the decade following the conflict, the level of financial support received by urban school districts permanently shifted upward. We provided the first quantitative analysis of the returns to these resources, highlighting several key facts about this historical event. First, overall increases in per pupil spending were generated by cities themselves, not transfers from state governments. Second, while all cities increased spending, urban areas with a larger share of enemy aliens saw proportionally larger growth in school resources. We argue this divergence was 
related to the assimilation prerogative of cities after the outbreak of World War I and use German share as an instrument for changes in school resources.

As in the present day, using endogenous increases in educational spending leads to estimated returns to school resources that are close to zero. However, using variation arising from the distribution of the German population leads to estimated returns that are statistically significant and economically meaningful. Our results suggest that war-driven increases in spending were an important part of the overall increase in educational attainment and wages across cohorts born at the end of the nineteenth and start of the twentieth century. Public education may thus have played an important role in the midcentury decline in inequality in the United States. 


\section{References}

(1918-1930). "Biennial Survey of Education," D. o. t. Interior, Washington, D.C.: Government Printing Office,

(1900-1916). "Report of the Commissoner of Education," Washington, D.C.: Government Printing Office,

Aaronson, Daniel, and Bhashkar Mazumder (2011). "The Impact of Rosenwald Schools on Black Achievement." Journal of Political Economy, 119(5), 821-88.

Abramitzky, Ran, Leah Platt Boustan, and Katherine Eriksson (2012). "Europe's Tired, Poor, Huddled Masses: Self-Selection and Economic Outcomes in the Age of Mass Migration." American Economic Review, 102(5), 1832-56.

(2014). "A Nation of Immigrants: Assimilation and Economic Outcomes in the Age of Mass Migration." Journal of Political Economy, 122(3), 467-506.

Abramitzky, Ran, Leah Platt Boustan, Elisa Jácome, and Santiago Pérez (2019).

"Intergenerational Mobility of Immigrants in the Us over Two Centuries," National Bureau of Economic Research,

Acemoglu, Daron, and Joshua Angrist (2000). "How Large Are Human-Capital Externalities? Evidence from Compulsory Schooling Laws." NBER macroeconomics annual, 15, 9-59.

Acemoglu, Daron, David H Autor, and David Lyle (2004). "Women, War, and Wages: The Effect of Female Labor Supply on the Wage Structure at Midcentury." Journal of Political Economy, 112(3), 497-551.

Akin, John S, and Irwin Garfinkel (1977). "School Expenditures and the Economic Returns to Schooling." Journal of human resources, 460-81.

Bailey, Martha, Connor Cole, Morgan Henderson, and Catherine Massey (2017). "How Well Do Automated Methods Perform in Historical Samples? Evidence from New Ground Truth," National Bureau of Economic Research,

Betts, Julian R (1996). "Is There a Link between School Inputs and Earnings." Does money matter, 141-91.

Card, David, Ciprian Domnisoru, and Lowell Taylor (2018). "The Intergenerational Transmission of Human Capital: Evidence from the Golden Age of Upward Mobility."

Card, David, and Alan B Krueger (1992). "Does School Quality Matter? Returns to Education and the Characteristics of Public Schools in the United States." Journal of Political Economy, 100(1), 1-40. 
Carruthers, Celeste K, and Marianne H Wanamaker (2017). "Separate and Unequal in the Labor Market: Human Capital and the Jim Crow Wage Gap." Journal of Labor Economics, 35(3), 65596.

Cascio, Elizabeth U, Nora Gordon, and Sarah Reber (2013). "Local Responses to Federal Grants: Evidence from the Introduction of Title I in the South." American Economic Journal: Economic Policy, 5(3), 126-59.

Clay, Karen, Jeff Lingwall, and Melvin Stephens Jr (2016). "Laws, Educational Outcomes, and Returns to Schooling: Evidence from the Full Count 1940 Census," National Bureau of Economic Research,

Coleman, James S, Ernest Campbell, Carol Hobson, James McPartland, Alexander Mood, Frederick Weinfeld, and Robert York (1966). "The Coleman Report." Equality of Educational Opportunity.

Collins, William J, and Gregory T Niemesh (2019). "Unions and the Great Compression of Wage Inequality in the Us at Mid-Century: Evidence from Local Labour Markets." The Economic History Review, 72(2), 691-715.

Cornman, Stephen Q. (2013). "Revenues and Expenditures for Public Elementary and Secondary School Districts: School Year 2009-10 (Fiscal Year 2010)." I. o. E. S. National Center for Education Statistics, U.S. Department of Education, Washington, D.C.:

De Chaisemartin, Clément, and Xavier D’HaultfCEuille (2017). "Fuzzy Differences-inDifferences." The Review of Economic Studies, 85(2), 999-1028.

Eisenberg, Martin Jay (1988). "Compulsory Attendance Legislation in America, 1870 to 1915."

Fouka, Vasiliki. "How do immigrants respond to discrimination? The case of Germans in the US during World War I." American Political Science Review 113.2 (2019): 405-422.

Goldin, Claudia, and Lawrence F Katz (2008). "Why the United States Led in Education: Lessons from Secondary School Expansion, 1910 to 1940."

Goldin, Claudia, and Robert A Margo (1992). "The Great Compression: The Wage Structure in the United States at Mid-Century." The Quarterly Journal of Economics, 107(1), 1-34.

Hanushek, Eric A (1986). "The Economics of Schooling: Production and Efficiency in Public Schools." Journal of economic literature, 24(3), 1141-77.

(1996). "School Resources and Student Performance." Does money matter? The effect of school resources on student achievement and adult success, 43-73.

Hickey, Donald R (1969). "The Prager Affair: A Study in Wartime Hysteria." Journal of the Illinois State Historical Society (1908-1984), 62(2), 117-34. 
Jackson, C. Kirabo, Rucker C. Johnson, and Claudia Persico (2016). "The Effects of School Spending on Educational and Economic Outcomes: Evidence from School Finance Reforms." The Quarterly Journal of Economics, 131(1), 157-218.

Juhnke, James C (1975). Mob Violence and Kansas Mennonites in 1918.

Lafortune, Julien, Jesse Rothstein, and Diane Whitmore Schanzenbach (2018). "School Finance Reform and the Distribution of Student Achievement." American Economic Journal: Applied Economics, 10(2), 1-26.

Land, Deborah (2002). "Local School Boards under Review: Their Role and Effectiveness in Relation to Students' Academic Achievement." Review of Educational Research, 72(2), 229-78.

Landes, William M, and Lewis C Solmon (1972). "Compulsory Schooling Legislation: An Economic Analysis of Law and Social Change in the Nineteenth Century." The Journal of Economic History, 32(1), 54-91.

Lavy, Victor (2015). "Teachers' Pay for Performance in the Long-Run: Effects on Students' Educational and Labor Market Outcomes in Adulthood," National Bureau of Economic Research,

Lleras-Muney, Adriana (2002). "Were Compulsory Attendance and Child Labor Laws Effective? An Analysis from 1915 to 1939." The Journal of Law and Economics, 45(2), 401-35.

Lleras-Muney, Adriana, and Allison Shertzer (2015). "Did the Americanization Movement Succeed? An Evaluation of the Effect of English-Only and Compulsory Schooling Laws on Immigrants." American Economic Journal: Economic Policy, 7(3), 258-90.

Margo, Robert A, and T Aldrich Finegan (1996). "Compulsory Schooling Legislation and School Attendance in Turn-of-the-Century America: A" Natural Experiment" Approach," National Bureau of Economic Research Cambridge, Mass., USA,

Morgan, James, and Ismail Sirageldin (1968). "A Note on the Quality Dimension in Education." Journal of Political Economy, 76(5), 1069-77.

Moser, Petra (2012). "Taste-Based Discrimination Evidence from a Shift in Ethnic Preferences after Wwi." Explorations in Economic History, 49(2), 167-88.

Officer, Lawrence H, and S Williamson (2018). "The Annual Consumer Price Index for the United States, 1774-2006." MeasuringWorth. com.

Ruggles, Steven, Sarah Flood, Ronald Goeken, Josiah Grover, Erin Meyer, Jose Pacas, and Matthew Sobek (2018). "Ipums USA: Version 8.0 [Dataset]," IPUMS, Minneapolis, MN: 
Schlossman, Steven L (1983). "Is There an American Tradition of Bilingual Education? German in the Public Elementary Schools, 1840-1919." American Journal of Education, 91(2), 139-86.

Strayer, George Drayton, and Robert Murray Haig (1923). The Financing of Education in the State of New York. Macmillan.

Swift, Fletcher H. (1924). "Biennial Survey of Education 1920-1922," D. o. t. Interior, Washington, D.C.: Government Printing Office,

Yerkes, Robert Mearns (1921). Psychological Examining in the United States Army: Edited by Robert M. Yerkes. US Government Printing Office.

Yockelson, Mitchel (1998). "The War Department: Keeper of Our Nation's Enemy Aliens During World War I," Annual Meeting of the Society for Military History. 1-5. 


\section{Figure 1: Trend in resources per pupil for sample cities (1900-1930)}

\section{Panel A. Real expenditures per pupil}

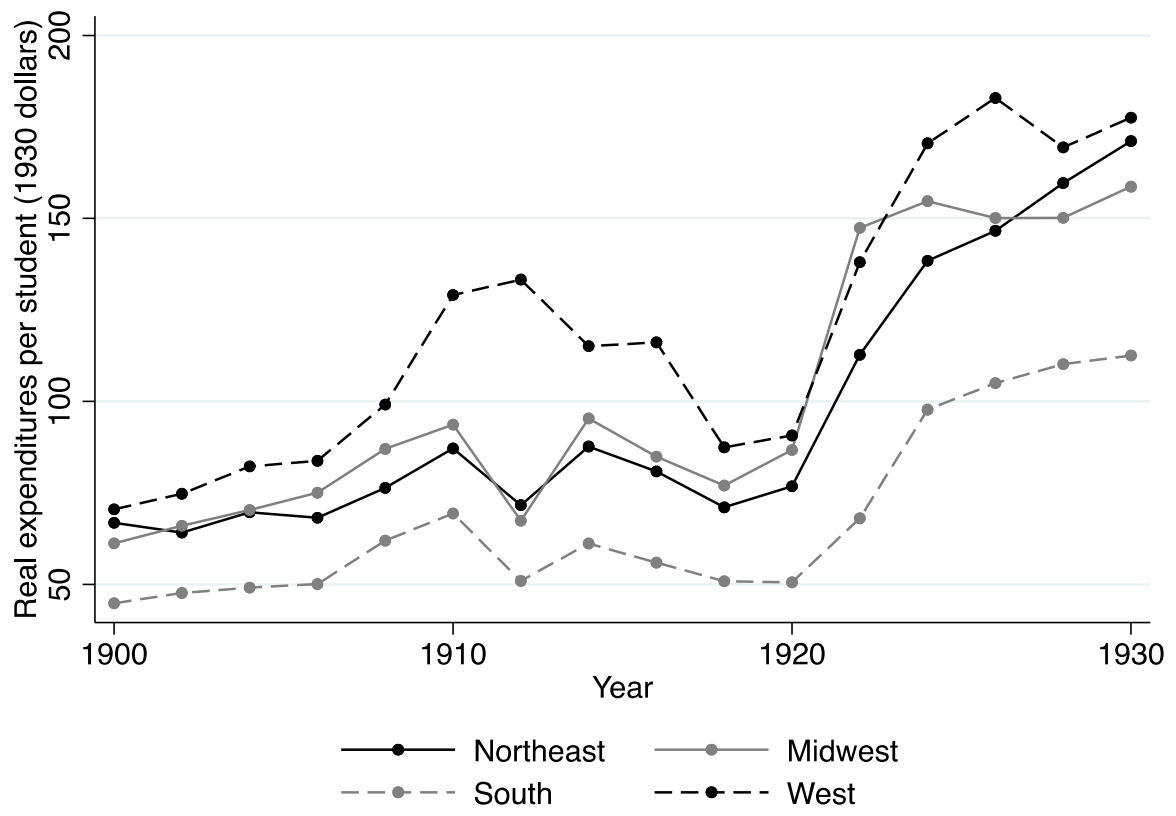

\section{Panel B. Pupil teacher ratio}

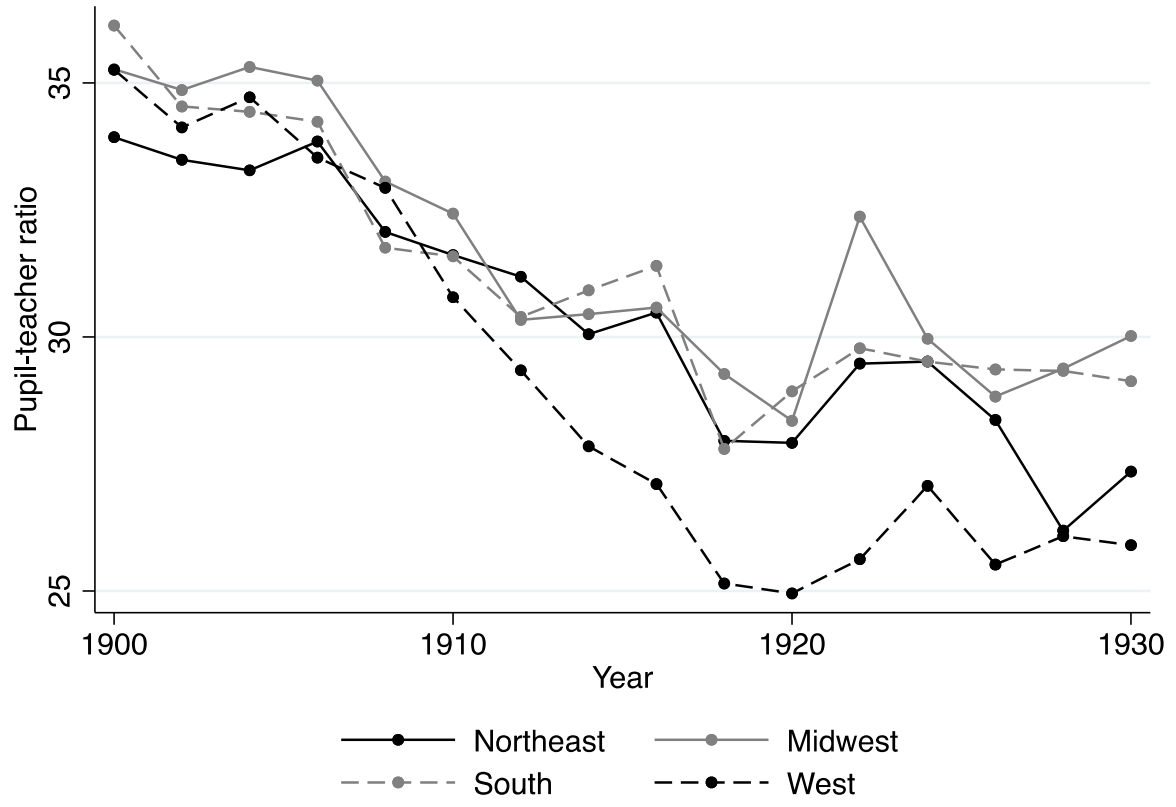

Notes: Data are averages for cities in each census region using our main sample (385 cities). Expenditures per pupil is the sum of expenditures on teachers, supervisors, capital, and other expenditures all divided by the average daily attendance in a school. Real expenditures per student are adjusted using the CPI from Officer and Williamson (2018); measuringworth.com/uscpi. The year of each data point corresponds to the calendar year in which the academic year ended (e.g. expenditures per pupil for the 1905-1906 academic year is plotted in 1906). The 1914-1915 academic year is plotted in 1916, since we could not find data for the 1915-1916 academic year. 
Figure 2: Sources of revenues for public schools for sample cities (1900-1930)

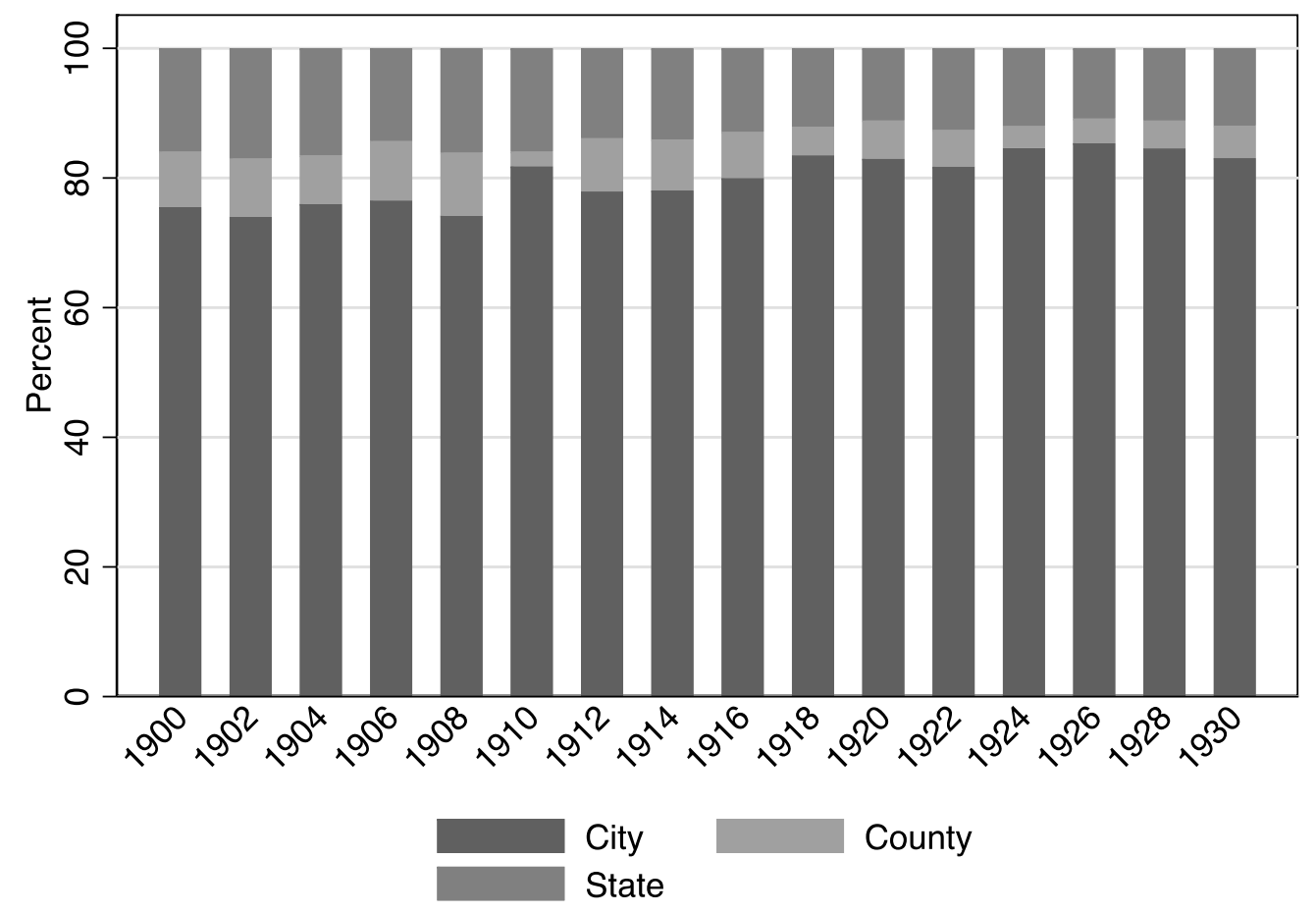

Notes: This graph shows the percentage of city school receipts that come from various levels of government. The year of each data point corresponds to the calendar year in which the academic year ended (e.g. expenditures per pupil for the 1905-1906 academic year is plotted in 1906). The 1914-1915 academic year is plotted in 1916, since we could not find data for the 1915-1916 academic year 


\section{Figure 3: The effect of state laws on state aid and total expenditures per student}

\section{Panel A. State aid}

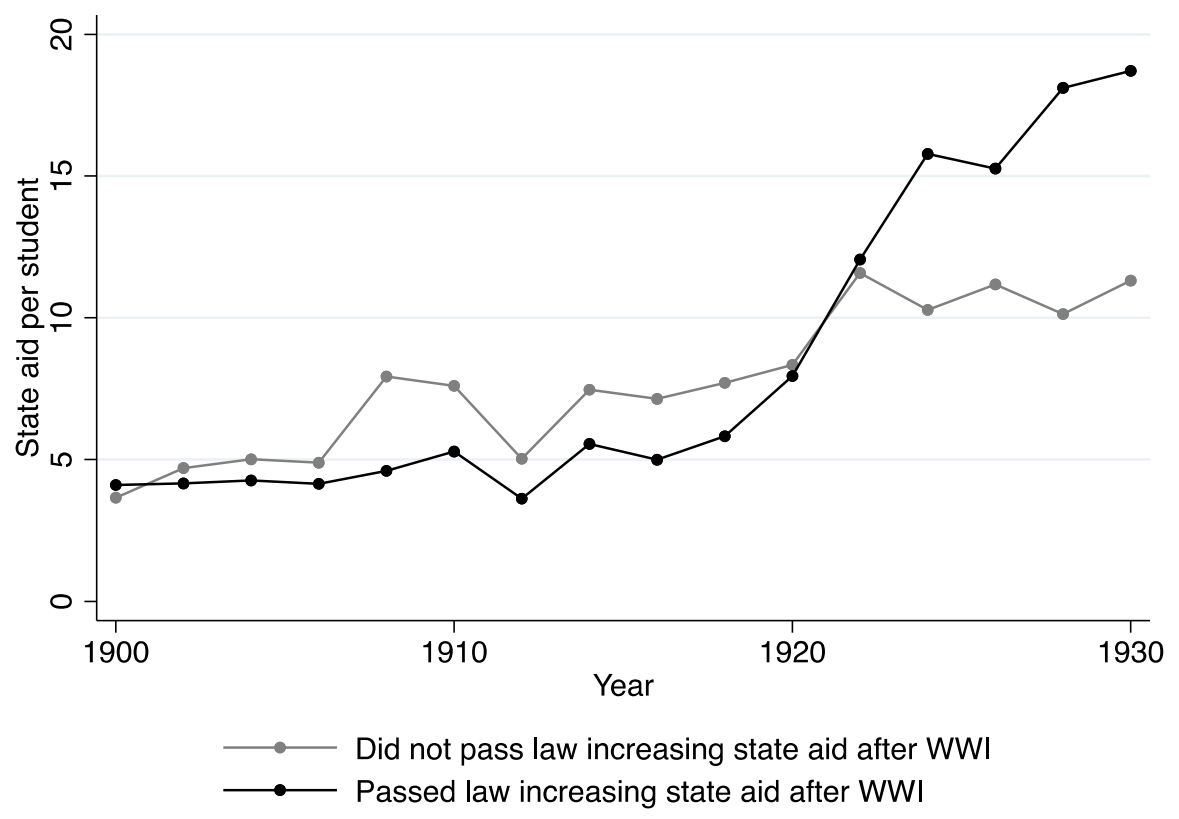

Panel B. Expenditures per pupil

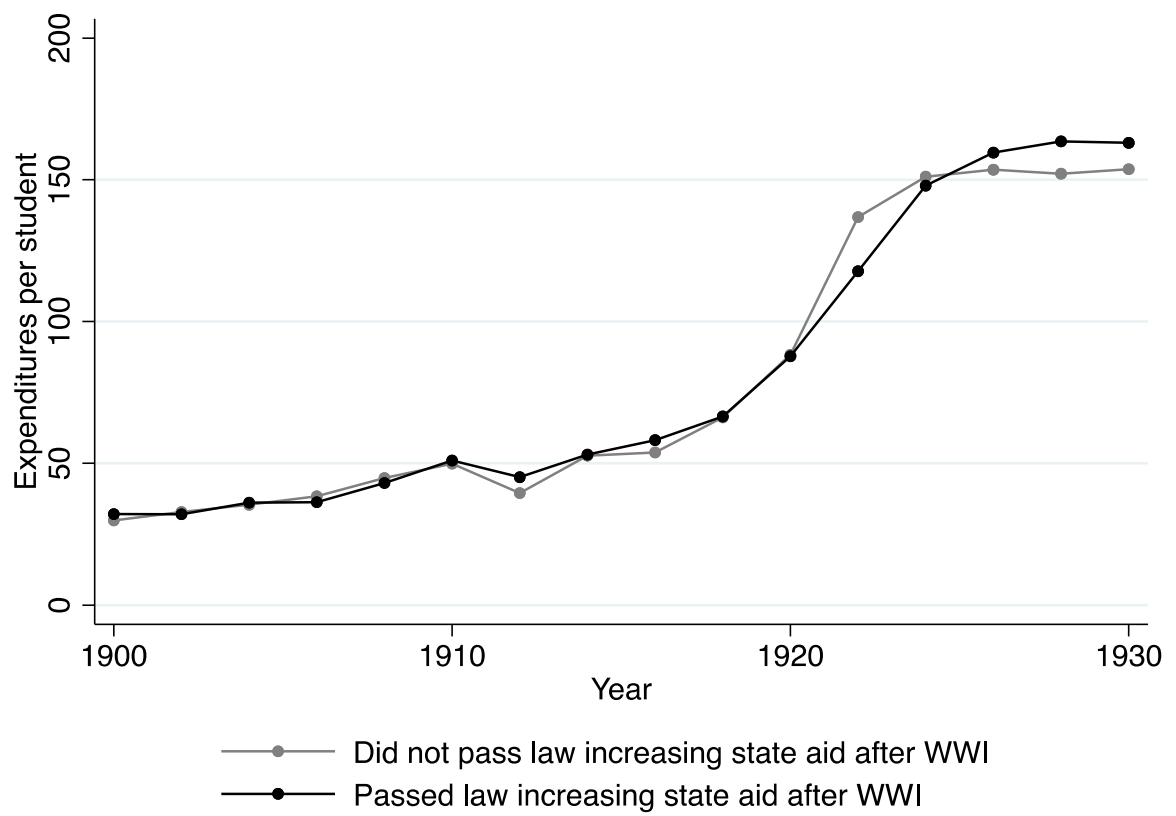

Notes: Data are averages for cities in each group of states. States the passed a law increasing state aid to schools after World War I include: Arizona, California, Georgia, Iowa, Louisiana, Massachusetts, New York, North Carolina, Pennsylvania, South Carolina, Texas, Utah, Washington, and West Virginia. See Figure 1 for a description of the data. 


\section{Figure 4. Growth in educational spending by category}

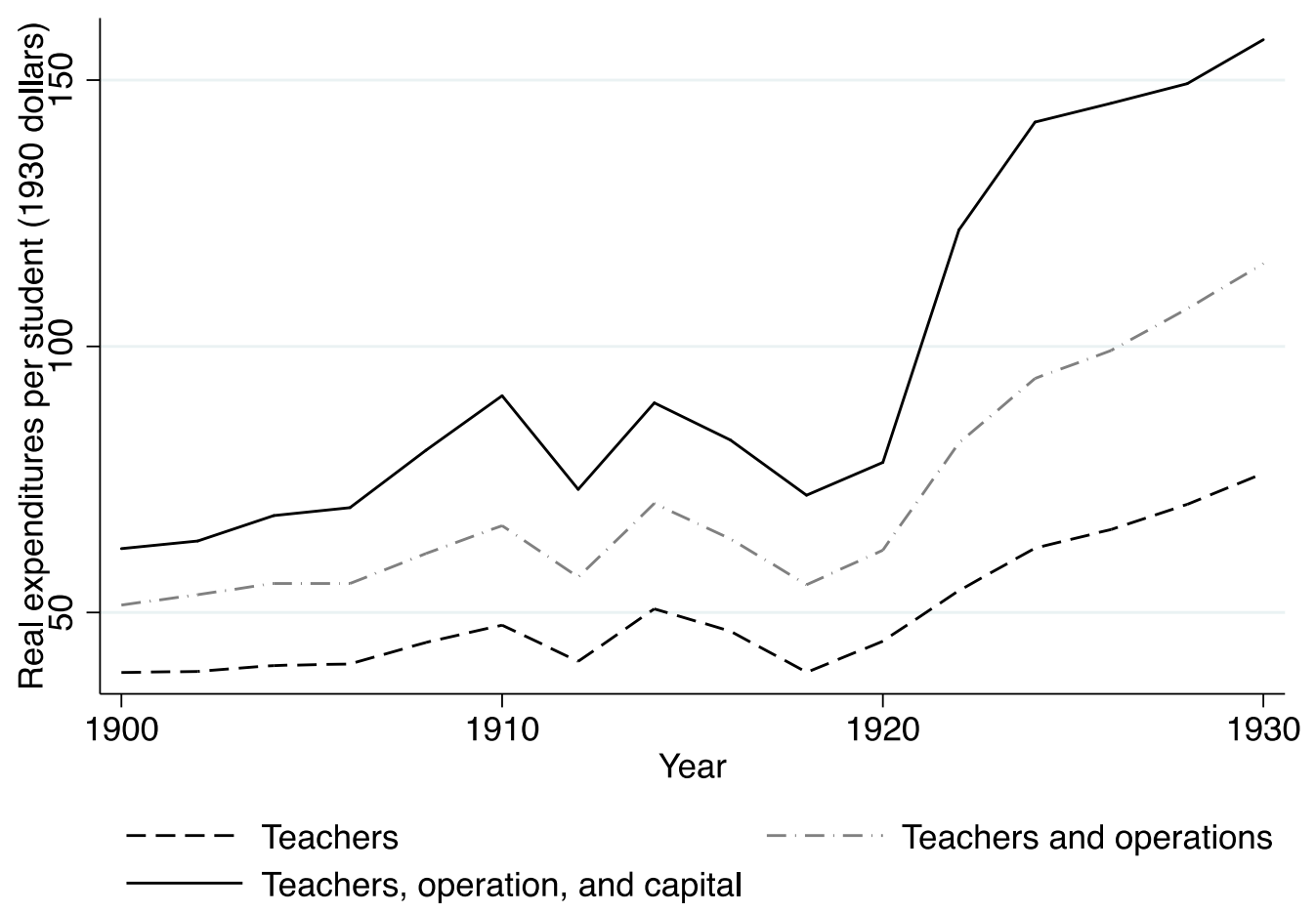

Notes: Data are averages for cities (385 cities). For each line, we divide expenditures on those categories by the average daily attendance in a school. Real expenditures per student are adjusted using the CPI from Officer and Williamson (2018); measuringworth.com/uscpi. The year of each data point corresponds to the calendar year in which the academic year ended (e.g. expenditures per pupil for the 1905-1906 academic year is plotted in 1906). The 19141915 academic year is plotted in 1916, since we could not find data for the 1915-1916 academic year. 
Figure 5: Growth in expenditures per pupil by German share

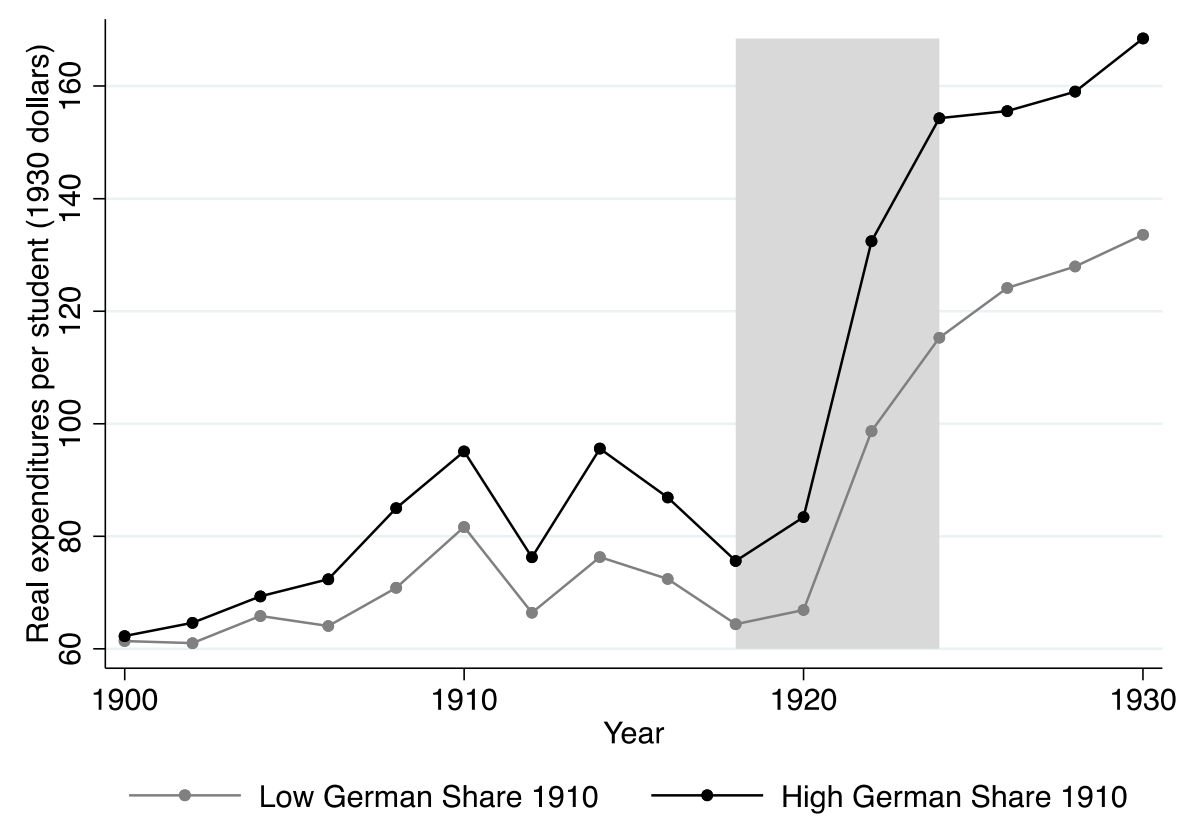

Notes: See Figure 1 for details on the data. "High" and "low" German share are defined as cities above and below the median German share, which is 2.16 percent of the population. 
Figure 6. Estimated differences in outcomes by German share of the city population

\section{Panel A. Educational attainment}

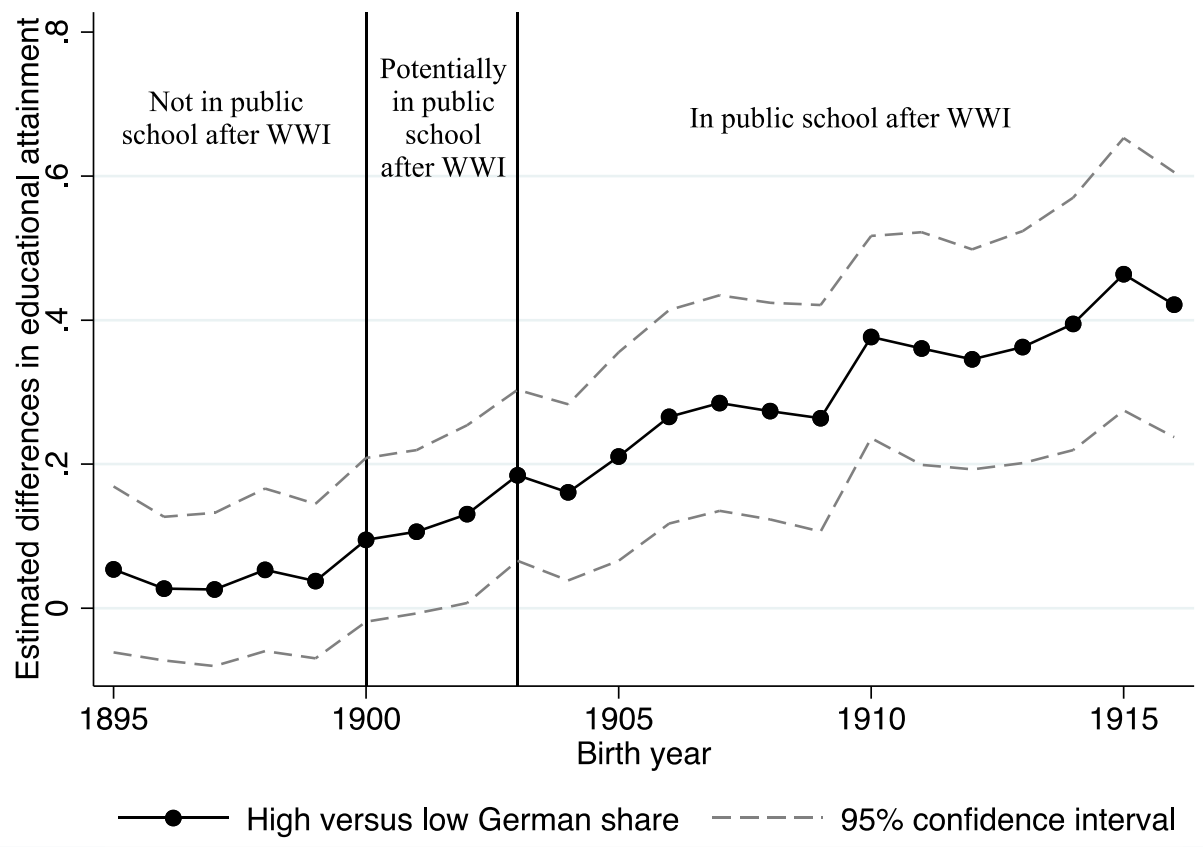

Panel B. Weekly wage

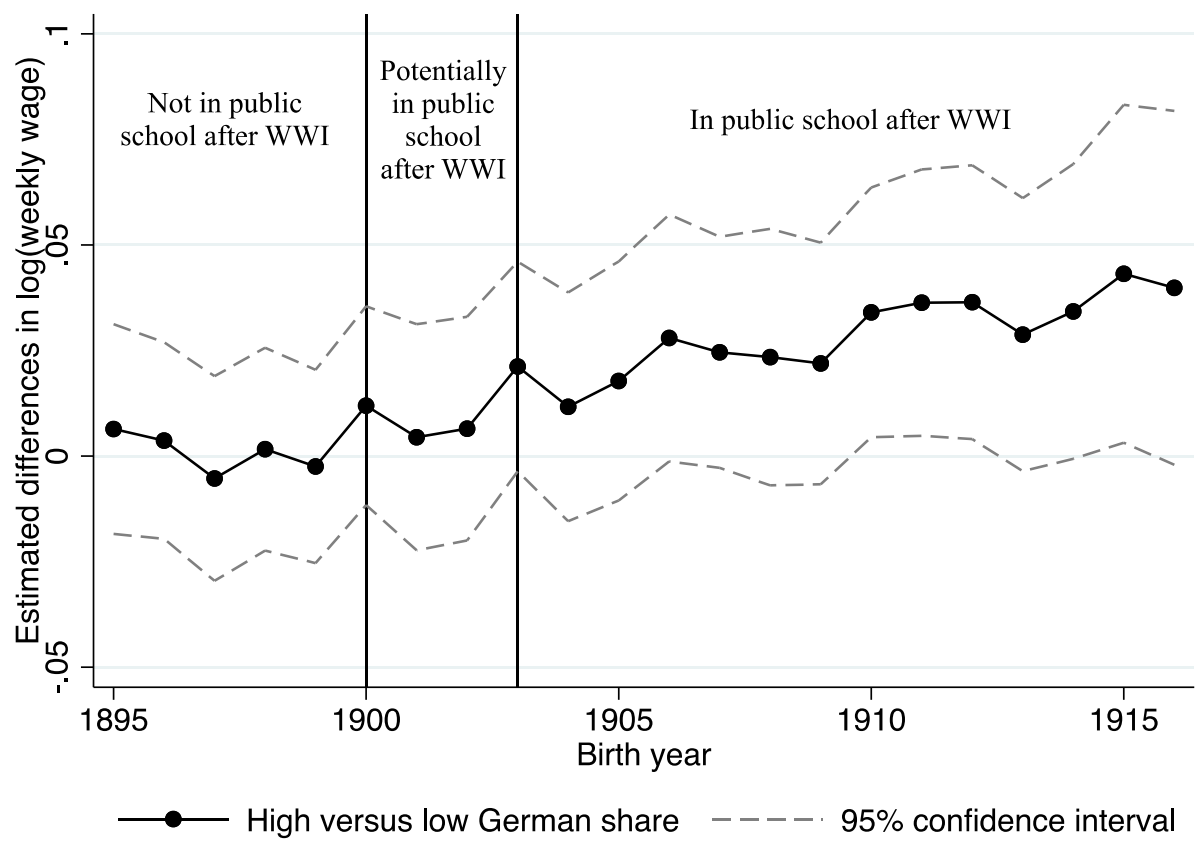

Notes: The figure graphs the coefficient estimates from equation (4) in the text. The points are the difference in outcomes between high and low-German-share cities relative to 1894 (the omitted year). 
Figure 7. Gap in education attainment in 1940 by father's SES

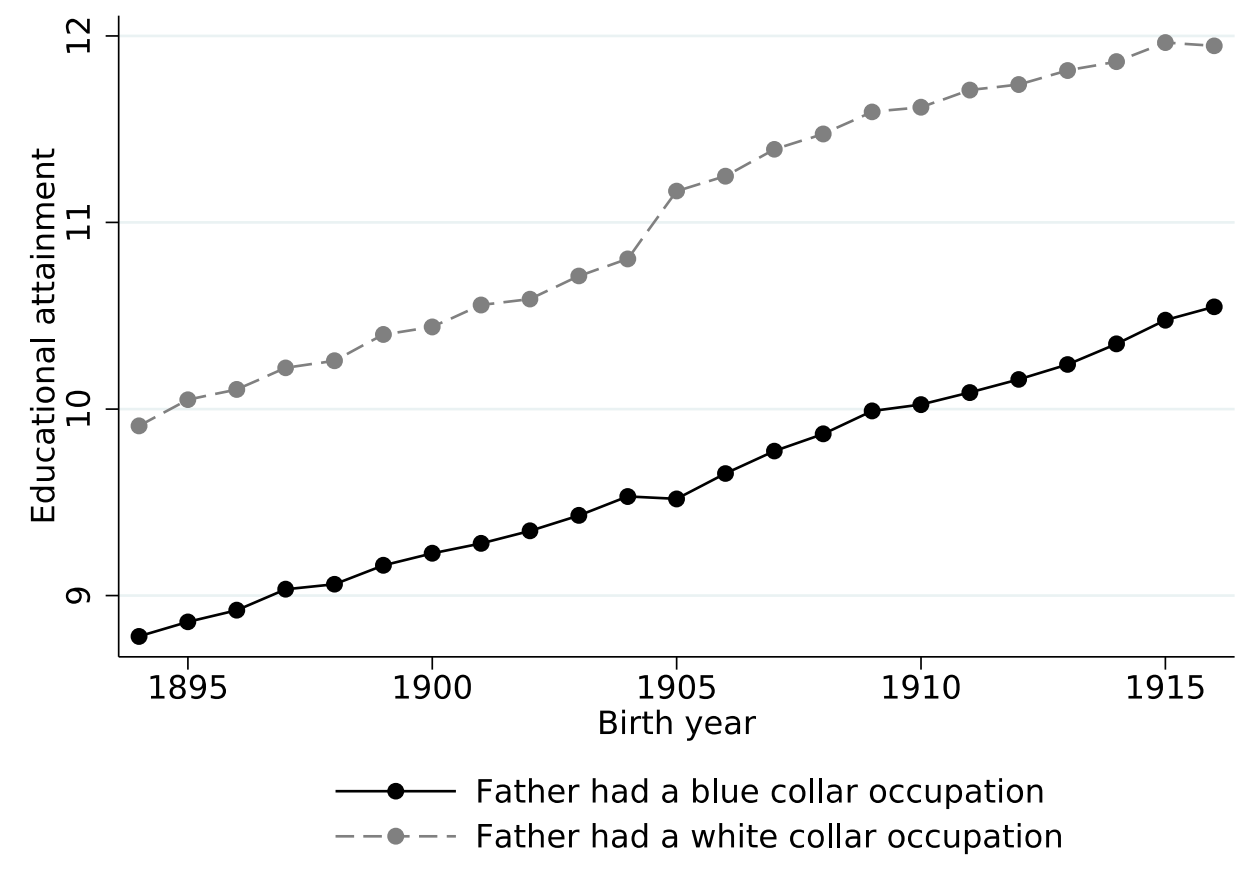

Notes: The plotted data is the average educational attainment of individual's in our sample whose father had a blueor white-collar occupation while the child was of school-age. 


\section{Table 1. Impacts of state educational funding laws}

\begin{tabular}{lccc}
\hline & Per student state aid & $\begin{array}{c}\text { Per student city } \\
\text { receipts }\end{array}$ & $\begin{array}{c}\text { Expenditures per } \\
\text { pupil } \\
\end{array}$ \\
& $(1)$ & $(2)$ & $(3)$ \\
Post WWI * State & $4.525^{* * *}$ & $-4.821^{* *}$ & 0.378 \\
Law & $(0.626)$ & $(2.062)$ & $(2.906)$ \\
& & & \\
$\mathrm{N}$ & 6160 & 6160 & 6160 \\
Cities & 385 & 385 & 385 \\
\hline \hline
\end{tabular}

Notes: The "Post WWI" variable is an indicator variable that takes a value of 1 for the years 1917-1930, and a 0 for the year 1900-1916. "Passed law increasing state aid after WWI" is an indicator if a city passed a law increasing state aid to schools after World War I. The states that passed these laws are: Arizona, California, Georgia, Iowa, Louisiana, Massachusetts, New York, North Carolina, Pennsylvania, South Carolina, Texas, Utah, Washington, and West Virginia. State revenue per student, city revenue per student, and expenditures per student are interpolated between two adjacent academic years when it is not reported for a city. All regressions control for city fixed effects and year fixed effects. Standard errors are in parentheses. $* \mathrm{p}<0.1, * * \mathrm{p}<0.05, * * * \mathrm{p}<0.01$. 
Table 2. Summary statistics

\begin{tabular}{lcccc}
\hline Panel A: City-level summary statistics & & & & \\
Academic Year: & $1899-$ & $1909-$ & $1919-$ & $1929-$ \\
& 1900 & 1910 & 1920 & 1930 \\
\cline { 2 - 5 } & & & & \\
Teacher and supervisor expenditures per & 16.74 & 23.75 & 44.16 & 66.52 \\
pupil & 4.84 & 10.93 & 16.88 & 36.68 \\
Capital and debt expenditures per pupil & 6.06 & 9.76 & 18.6 & 36.72 \\
Other expenditures per pupil & 27.64 & 44.44 & 79.64 & 139.92 \\
Total expenditures per pupil & 34.53 & 30.86 & 27.86 & 28.05 \\
Pupil-teacher ratio & 18.3 & 28.17 & 56.96 & 95.4 \\
School revenues from city per pupil & 4.45 & 6.52 & 7.89 & 14.66 \\
School revenues from state per pupil & 2.95 & 1.2 & 3.9 & 4.48 \\
School revenues from county per pupil & 385 & 385 & 385 & 385 \\
Observations & & & &
\end{tabular}

Panel B: Individual-level summary statistics for individuals who have a weekly wage

Census:

Weekly wage (1940)

White-collar job (1940)

Educational attainment

Completed 8th grade

High school graduate

Real per pupil spending (average ages 6-14)

Years of post-WWI schooling

Age (1940)

Mother present?

Mother literate if present?

Father present?

Father literate if present?

High SES HH

Low SES HH

Could not determine SES

\begin{tabular}{cccc}
1900 & 1910 & 1920 & 1930 \\
\hline$\$ 38.36$ & $\$ 36.66$ & $\$ 29.46$ & $\$ 23.13$ \\
0.4 & 0.41 & 0.39 & 0.34 \\
9.25 & 9.64 & 10.47 & 10.88 \\
0.81 & 0.84 & 0.91 & 0.94 \\
0.26 & 0.3 & 0.41 & 0.51 \\
$\$ 68.97$ & $\$ 81.06$ & $\$ 100.73$ & $\$ 144.53$ \\
0 & 0 & 5.39 & 8 \\
45.8 & 40.25 & 30.39 & 24.52 \\
0.97 & 0.95 & 0.96 & 0.96 \\
0.92 & 0.94 & 0.93 & 0.95 \\
0.94 & 0.9 & 0.91 & 0.91 \\
0.95 & 0.96 & 0.95 & 0.96 \\
0.17 & 0.23 & 0.17 & 0.14 \\
0.56 & 0.61 & 0.48 & 0.42 \\
0.27 & 0.16 & 0.35 & 0.44
\end{tabular}

Observations

$17,813 \quad 510,896$

739,786

189,579

Notes: Data in Panel A are from the Report of the Commissioner of Education (1900-1916) and the Biennial Survey of Education (1918-1930). Data in Panel B are from the linked census sample. 
Table 3. Difference in characteristics of cities by German share

\begin{tabular}{|c|c|c|c|c|c|}
\hline & \multicolumn{2}{|c|}{$\begin{array}{l}\text { Below median German } \\
\text { share }\end{array}$} & \multicolumn{2}{|c|}{$\begin{array}{c}\text { Above median German } \\
\text { share }\end{array}$} & \multirow{2}{*}{$\begin{array}{c}\begin{array}{c}\text { Equality } \\
\text { of means }\end{array} \\
\text { p-value }\end{array}$} \\
\hline & Mean & Std dev. & Mean & Std dev. & \\
\hline \multicolumn{6}{|c|}{ Panel A: Region cities are located in } \\
\hline In Northeast & 111 & & 70 & & \\
\hline In Midwest & 33 & & 94 & & \\
\hline In South & 45 & & 9 & & \\
\hline In West & 3 & & 20 & & \\
\hline Total & 192 & & 193 & & \\
\hline \multicolumn{6}{|l|}{ Panel B: Demographics } \\
\hline Share German & 0.0099 & $(0.0061)$ & 0.0505 & $(0.0309)$ & $0.000 * * *$ \\
\hline Share Irish & 0.0259 & $(0.0285)$ & 0.0211 & $(0.0220)$ & $0.067 *$ \\
\hline Share Italian & 0.0155 & $(0.0225)$ & 0.0193 & $(0.0236)$ & 0.103 \\
\hline Share Russian & 0.0171 & $(0.0330)$ & 0.0209 & $(0.0237)$ & 0.195 \\
\hline Share Foreign Born & 0.1752 & $(0.1310)$ & 0.2181 & $(0.0986)$ & $0.003 * * *$ \\
\hline Share Black & 0.0909 & $(0.1422)$ & 0.0249 & $(0.0380)$ & $0.000 * * *$ \\
\hline Average population in 1910 & 40,208 & $(65,276)$ & 91,210 & $(215,815)$ & $0.002 * * *$ \\
\hline
\end{tabular}

Panel C: Share of county population in 1910 employed as:

White collar

$\begin{array}{llllc}0.1948 & (0.0510) & 0.2125 & (0.0522) & 0.001 * * * \\ 0.1017 & (0.0825) & 0.0956 & (0.0717) & 0.445 \\ 0.1409 & (0.0396) & 0.1576 & (0.0394) & 0.000^{* * *} \\ 0.1993 & (0.1239) & 0.1685 & (0.0989) & 0.007 * * * \\ 0.1134 & (0.0513) & 0.0978 & (0.0274) & 0.002 * * * \\ 0.2061 & (0.0731) & 0.2174 & (0.0626) & 0.105\end{array}$

Farmer

Craftsman

Operatives

0.2061

$(0.0731)$

$0.2174 \quad(0.0626)$

0.105

Panel D: Change in share of county population (1910-1920) employed as:

White collar

$\begin{array}{ccccc}0.0429 & (0.0240) & 0.0438 & (0.0233) & 0.719 \\ -0.0039 & (0.0211) & 0.0000 & (0.0240) & 0.085^{*} \\ 0.0181 & (0.0244) & 0.0194 & (0.0247) & 0.595 \\ 0.0096 & (0.0252) & 0.0103 & (0.0259) & 0.794 \\ -0.0239 & (0.0166) & -0.0217 & (0.0117) & 0.143 \\ -0.0258 & (0.0328) & -0.0301 & (0.0290) & 0.176\end{array}$

Farmer

Craftsman

Operatives

Service

Laborers

192

193

Notes: This table shows city averages for our 385 sample cities using full count census data from 1910. There are 192 cities in the "Below median German share" group and 193 cities in the "Above median German share" group. White collar workers are defined as professional, managers, officials, proprietors, clerks, and sales workers. The final column provides the $\mathrm{p}$-value from a test for the equality of the means. ${ }^{*} \mathrm{p}<0.1,{ }^{*} \mathrm{p}<0.05, * * * \mathrm{p}<0.01$. 


\section{Table 4. Validity of German share instrument}

\section{Panel A: Educational expenditures}

Post WWI*High German share (1910)

Post WWI* $\log ($ German share (1910))

Post WWI*High non-English speaking, non-German share (1910)

Post WWI* $\log ($ Non-English speaking, non-German share (1910))

\begin{abstract}
$\mathrm{N}$
\end{abstract}
Cities

Log(real expenditures per student, 1930 dollars)

(1)

0.0422 *

(0.0227)
(2)

$0.0284 * * *$

(0.0108)

\subsection{8}

(0.0228)

\begin{tabular}{cccc}
6160 & & & $(0.0107)$ \\
385 & 6160 & 6160 & 6160 \\
& 385 & 385 & 385 \\
\hline
\end{tabular}

(4)

\begin{tabular}{|c|c|c|c|c|c|c|}
\hline \multicolumn{7}{|c|}{ Panel B: Non-educational public expenditures } \\
\hline \multirow[t]{2}{*}{ Dependent variable: } & \multicolumn{2}{|c|}{$\log (\exp$. on fire $)$} & \multicolumn{2}{|c|}{ Log(exp. on police) } & \multicolumn{2}{|c|}{$\log (\exp$. on sewer $)$} \\
\hline & (1) & (2) & (3) & (4) & (5) & (6) \\
\hline \multirow[t]{2}{*}{ Post WWI*High German share (1910) } & -0.0831 & & -0.0161 & & -0.00393 & \\
\hline & $(0.0832)$ & & $(0.0794)$ & & $(0.127)$ & \\
\hline \multirow[t]{2}{*}{ Post WWI*German share (1910) } & & -0.0322 & & 0.00698 & & 0.0659 \\
\hline & & $(0.0313)$ & & $(0.0245)$ & & $(0.0512)$ \\
\hline $\mathrm{N}$ & 1600 & 1600 & 1600 & 1600 & 1600 & 1600 \\
\hline Cities & 100 & 100 & 100 & 100 & 100 & 100 \\
\hline
\end{tabular}

Notes: The "Post WWI" variable is an indicator variable that takes a value of 1 for the years 1917-1930, and a 0 for the years 1900-1916. "High German share (1910)" is an indicator if a city had above median German share of the population in 1910. "High non-English speaking, non-German share (1910)" is an indicator if a city had an above median non-English speaking, non-German share of the population. Immigrants from non-English speaking countries are defined as immigrants that are not from Canada, England, Ireland, Northern Ireland, Scotland, and Wales. Finally, "German share (1910)" and "Non-English speaking, nonGerman share (1910)" are standardized measures of the German share and Non-English speaking, non-German share of the population that have a mean of zero and standard deviation of one. Expenditures per student is interpolated between two adjacent academic years when it is not reported for a city. All regressions control for city fixed effects and year fixed effects. Spending on fire, police, and sewer services were provided by Elyce Rotella and Louis Cain. Standard errors are in parentheses. $* \mathrm{p}<0.1, * * \mathrm{p}<0.05, * * * \mathrm{p}<0.01$ 
Table 5. OLS and 2SLS estimates of expenditures per pupil on adult outcomes

\begin{tabular}{lccccc}
\hline Dependent variable: & $\begin{array}{c}\text { Educational } \\
\text { attainment }\end{array}$ & $\begin{array}{c}\operatorname{Pr}(8 \text { th grade } \\
\text { completed =1) }\end{array}$ & $\begin{array}{c}\operatorname{Pr}(\text { High school } \\
\text { graduate =1) }\end{array}$ & $\begin{array}{c}\text { Log(weekly } \\
\text { wage })\end{array}$ & $\begin{array}{c}\text { Pr(white-collar } \\
\text { job =1) }\end{array}$ \\
\cline { 2 - 6 } & $(1)$ & $(2)$ & $(3)$ & $(4)$ & $(5)$ \\
Panel A: Panel estimates & & & & & \\
Log(expenditures per pupil) & $\begin{array}{c}0.124^{* *} \\
(0.0505)\end{array}$ & $\begin{array}{c}0.0158^{* *} \\
(0.00679)\end{array}$ & -0.000701 & 0.0116 & -0.00700 \\
& & & $(0.00931)$ & $(0.00864)$ & $(0.00641)$
\end{tabular}

Panel B: 2SLS estimates

$\begin{array}{lccccc}\text { Log(expenditures per pupil) } & 1.649 * * * & 0.170 * * & 0.176^{* * *} & 0.145^{* *} & 0.0201 \\ & (0.453) & (0.0666) & (0.0684) & (0.0661) & (0.0321) \\ & & & & & 11.92 \\ \text { First stage F-statistics } & 11.92 & 11.92 & 11.92 & 11.92 & 1458074 \\ \mathrm{~N} & 1458074 & 1458074 & 1458074 & 1458074 & 385 \\ \text { Cities } & 385 & 385 & 385 & 385 & \end{array}$

Notes: Panel A provides estimates of equation (2) in the text. The key treatment variable, $\log ($ expenditures per pupil) is average per pupil spending (in real 1930 dollars) during school-age years (ages 6-14). Expenditures per pupil is the sum of expenditures on teachers, supervisors, capital, and other expenditures all divided by the average daily attendance in a school. All regressions control for: city of education fixed effects, cohort fixed effects, mother's literacy (mother literate, mother illiterate, and mother not present), father's literacy (father literate, father illiterate, and father not present), mother's occupation (dummies), father's occupation (dummies), and the average percent of a city's population that reports working in one of the following industries during a child's school-age years: white collar (professional, manager, clerk, or salesmen), craftsman, operator, service worker, laborer, or farmer. Non-occupational responses are the omitted category. These percentages were constructed from the 1900-1930 IPUMS (Ruggles et al. 2018) complete count data and are interpolated in-between census years. Panel B provides 2SLS estimates of equations (4) in the text. The excluded instrument in the second stage regression is (the number of years of exposure to post-WWI schooling) $\mathrm{x}$ (the log of the German share of a city's population in 1910). The number of years of exposure to post-WWI schooling is defined as the number of school-age years (ages 6-14) that occurred during or after 1917. Standard errors are in parentheses. * $\mathrm{p}<0.1, * * \mathrm{p}<0.05, * * * \mathrm{p}<0.01$. 
Table 6. 2SLS estimates of the return to school resources with region-specific time trends

\begin{tabular}{lccccc}
\hline Dependent variable: & $\begin{array}{c}\text { Educational } \\
\text { attainment }\end{array}$ & $\begin{array}{c}\text { Pr(8th grade } \\
\text { completed =1) }\end{array}$ & $\begin{array}{c}\text { Pr(High school } \\
\text { graduate =1) }\end{array}$ & $\begin{array}{c}\text { Log(weekly } \\
\text { wage) }\end{array}$ & $\begin{array}{c}\text { Pr(white-collar } \\
\text { job = 1) }\end{array}$ \\
\cline { 2 - 6 } & $(1)$ & $(2)$ & $(3)$ & $(4)$ & $(5)$ \\
Log(capital expenditures per pupil) & $1.078^{* * *}$ & $0.153^{* *}$ & 0.0669 & $0.119^{* *}$ & 0.0362 \\
& $(0.392)$ & $(0.0681)$ & $(0.0520)$ & $(0.0576)$ & $(0.0309)$ \\
First stage F-statistics & & & & 9.62 & 9.62 \\
N & 9.62 & 9.62 & 9.62 & 1458074 & 1458074 \\
Cities & 1458074 & 1458074 & 1458074 & 385 & 385 \\
\hline \hline
\end{tabular}

Notes: This table provides 2SLS estimates of equations (4) in the text with the addition of linear time trends for each of the four census regions. See Table 5 for details on the sample and variable definitions. 


\section{Table 7. Effect of school resources on adult outcomes by socioeconomic status}

\begin{tabular}{|c|c|c|c|c|c|c|c|c|c|c|}
\hline \multirow{3}{*}{$\begin{array}{l}\text { Dependent variable: } \\
\text { Model: }\end{array}$} & \multicolumn{2}{|c|}{$\begin{array}{l}\text { Educational } \\
\text { attainment }\end{array}$} & \multicolumn{2}{|c|}{$\begin{array}{c}\operatorname{Pr}(8 \text { th grade } \\
\text { completed = 1) }\end{array}$} & \multicolumn{2}{|c|}{$\begin{array}{l}\text { Pr(High school } \\
\text { graduate }=1)\end{array}$} & \multicolumn{2}{|c|}{ Log weekly wage } & \multicolumn{2}{|c|}{$\begin{array}{c}\text { Pr(white collar } \\
\text { employment = 1) }\end{array}$} \\
\hline & OLS & 2SLS & OLS & 2SLS & OLS & $2 \mathrm{SLS}$ & OLS & 2SLS & OLS & 2SLS \\
\hline & (1) & (2) & (3) & (4) & (5) & (6) & $(7)$ & (8) & (9) & (10) \\
\hline \multicolumn{11}{|c|}{ Panel A: Father had a blue-collar occupation (craftsman, operator, service worker, or laborer) } \\
\hline $\begin{array}{l}\text { Log(expenditures per } \\
\text { pupil) }\end{array}$ & $\begin{array}{c}0.152 * * * \\
(0.0516)\end{array}$ & $\begin{array}{l}1.919 * * * \\
(0.514)\end{array}$ & $\begin{array}{l}0.0193 * * \\
(0.00820)\end{array}$ & $\begin{array}{l}0.218 * * * \\
(0.0827)\end{array}$ & $\begin{array}{l}-0.00115 \\
(0.0104)\end{array}$ & $\begin{array}{l}0.175 * * \\
(0.0726)\end{array}$ & $\begin{array}{c}0.0119 \\
(0.0106)\end{array}$ & $\begin{array}{l}0.156 * * \\
(0.0739)\end{array}$ & $\begin{array}{c}0.00214 \\
(0.00594)\end{array}$ & $\begin{array}{l}0.0573 * * \\
(0.0281)\end{array}$ \\
\hline First stage F statistic & NA & 12.27 & NA & 12.27 & NA & 12.27 & NA & 12.27 & NA & 12.27 \\
\hline $\mathrm{N}$ & 754238 & 754238 & 754238 & 754238 & 754238 & 754238 & 754238 & 754238 & 754238 & 754238 \\
\hline \multicolumn{11}{|c|}{ Panel B: Father had a white-collar occupation (professional, manager, proprietor, clerk, or salesman) } \\
\hline $\begin{array}{l}\text { Log(expenditures per } \\
\text { pupil) }\end{array}$ & $\begin{array}{c}0.0583 \\
(0.0545)\end{array}$ & $\begin{array}{l}1.512 * * * \\
(0.508)\end{array}$ & $\begin{array}{c}0.00418 \\
(0.00631)\end{array}$ & $\begin{array}{c}0.0424 \\
(0.0306)\end{array}$ & $\begin{array}{l}0.00555 \\
(0.0104)\end{array}$ & $\begin{array}{l}0.254 * * * \\
(0.0862)\end{array}$ & $\begin{array}{l}-0.00061 \\
(0.0104)\end{array}$ & $\begin{array}{c}0.0841 \\
(0.0600)\end{array}$ & $\begin{array}{c}-0.0111 \\
(0.00918)\end{array}$ & $\begin{array}{c}0.0403 \\
(0.0401)\end{array}$ \\
\hline First stage F statistic & NA & 12.16 & NA & 12.16 & NA & 12.16 & NA & 12.16 & NA & 12.16 \\
\hline $\mathrm{N}$ & 277428 & 277428 & 277428 & 277428 & 277428 & 277428 & 277428 & 277428 & 277428 & 277428 \\
\hline
\end{tabular}

Notes: Panel A and B provide estimates of equation (2) and (4) in the text. All regressions control for: city of education fixed effects, cohort fixed effects, mother's literacy (mother literate, mother illiterate, and mother not present), father's literacy (father literate, father illiterate, and father not present), mother's occupation (dummies), father's occupation (dummies), and the average percent of a city's population that reports working in one of the following industries during a child's school-age years: white collar (professional, manager, clerk, or salesmen), craftsman, operator, service worker, laborer, or farmer. Non-occupational responses are the omitted category. These percentages were constructed from the 1900-1930 IPUMS (Ruggles et al. 2018) complete count data and are interpolated in-between census years. The excluded instrument in the second stage regressions is (the number of years of exposure to post-WWI schooling) x (the log of the German share of a city's population in 1910). The number of years of exposure to post-WWI schooling is defined as the number of school-age years (ages 6-14) that occurred during or after 1917. Standard errors are in parentheses. $* \mathrm{p}<0.1, * * \mathrm{p}<0.05, * * * \mathrm{p}<0.01$. 


\section{Appendix}

Figure A.I. Geographical Distribution of Sample Cities

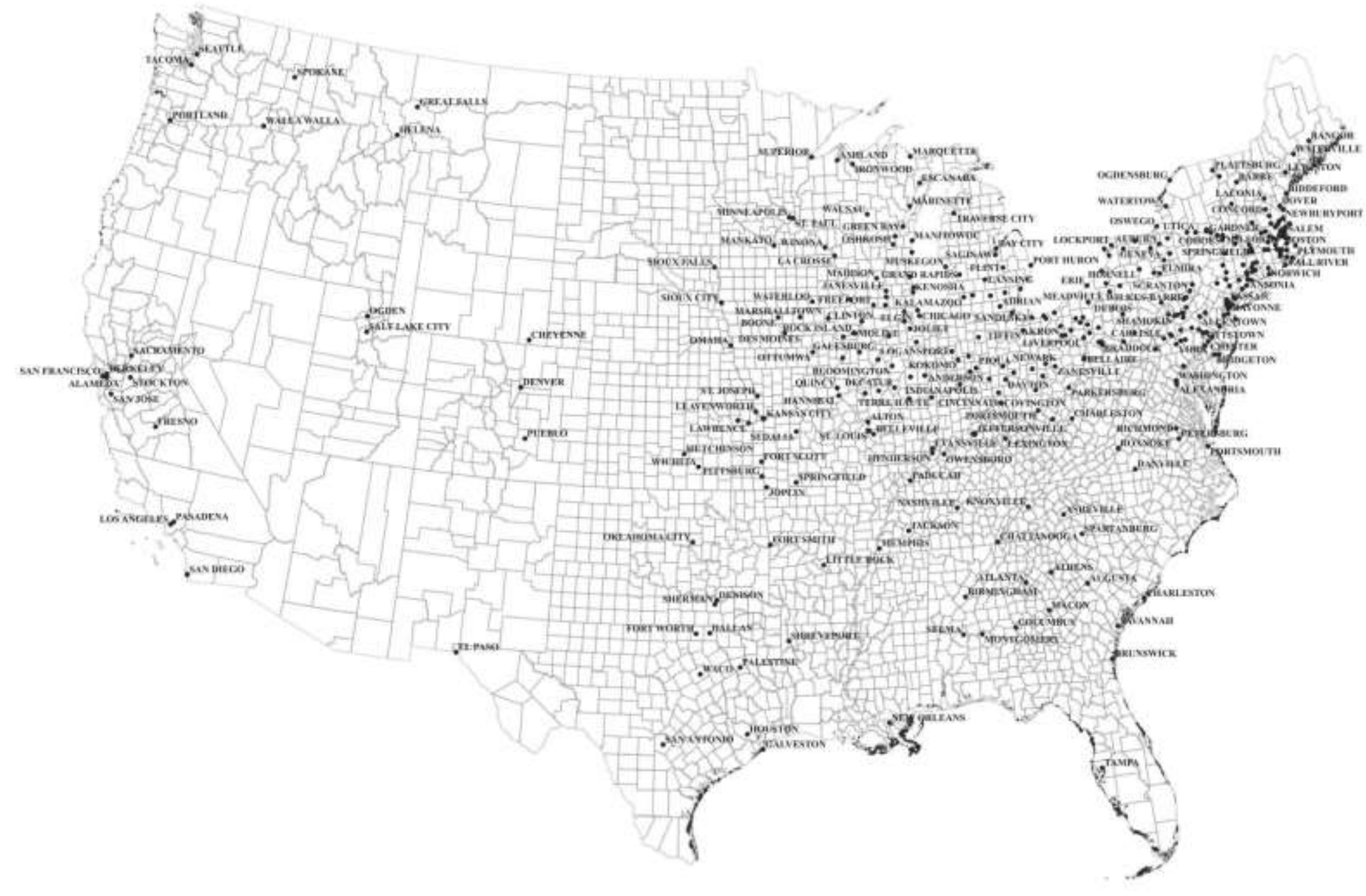


Figure A.II. Histogram of educational attainment in our sample

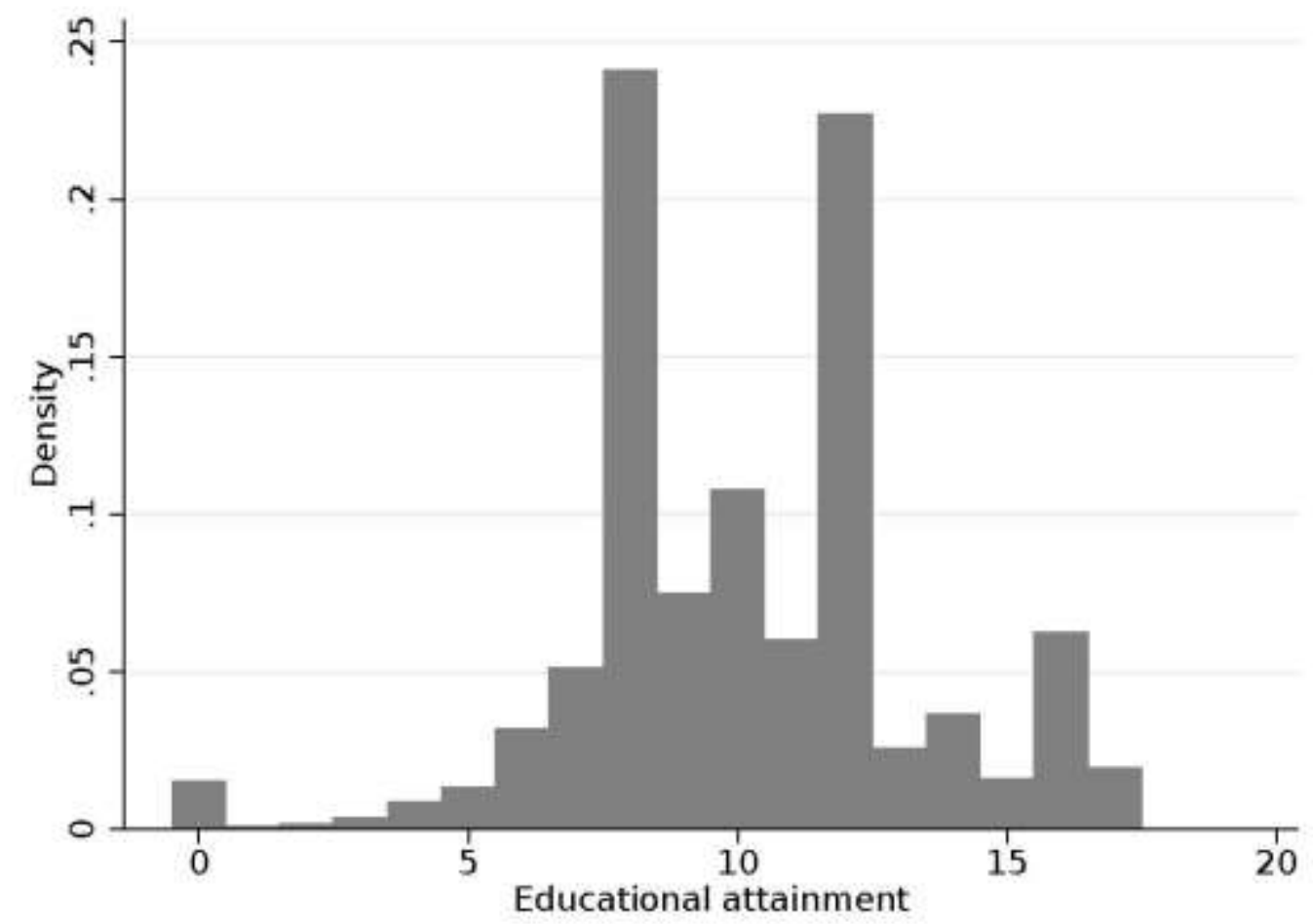

Notes: This figure is a histogram of educational attainment for white men who were not in the top or bottom one percent of weekly wage earners in our sample. 
Figure A.III. Estimated differences in school spending by city German share

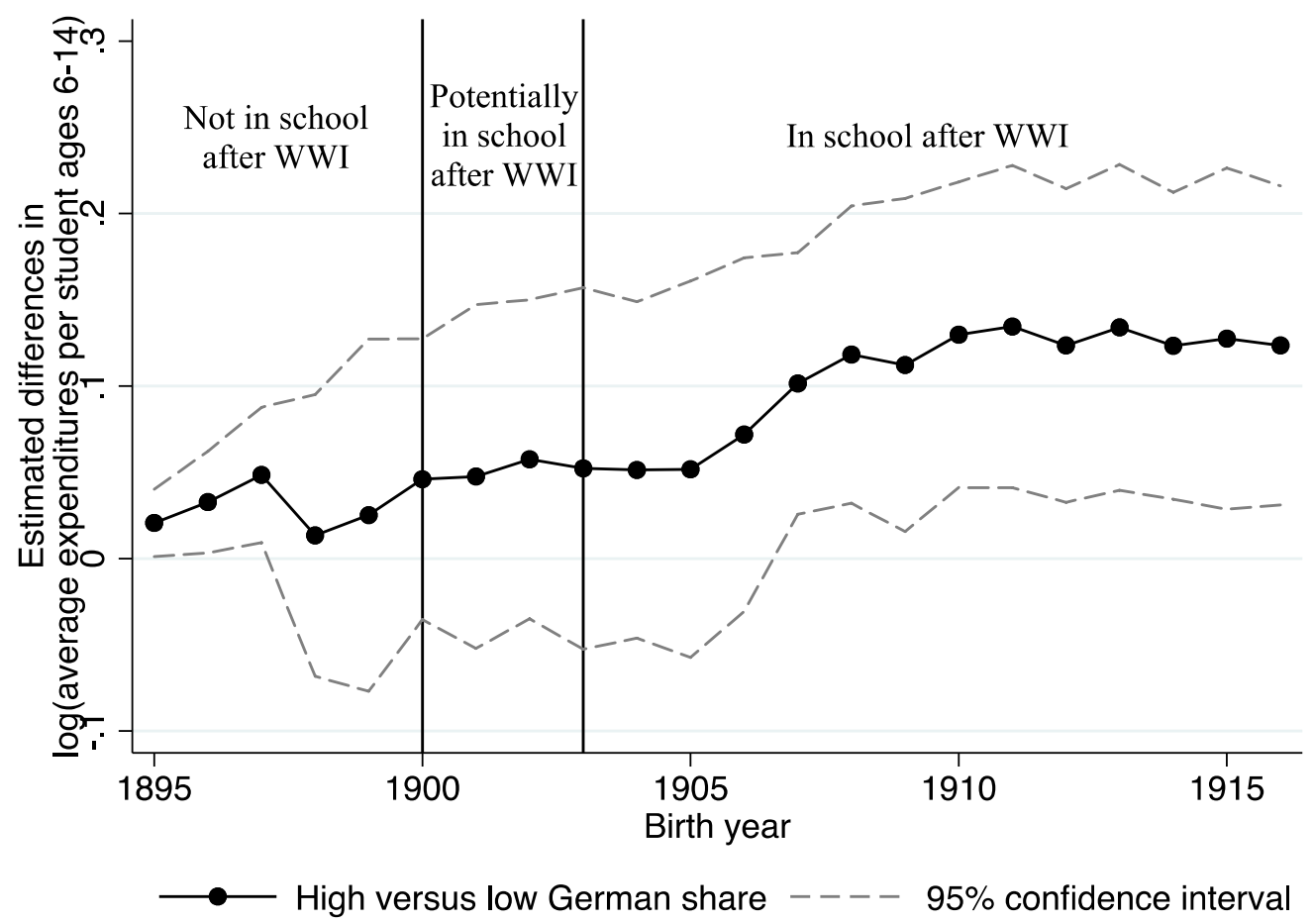

Notes: The figure graphs the coefficient estimates from equation (4) in the text. The points are the difference in outcomes between high and low-German-share cities relative to 1894 (the omitted year). 
Table A.I. Matching Process Outcomes

\begin{tabular}{|c|c|c|c|c|c|c|c|c|}
\hline \multirow[t]{2}{*}{ Census Year: } & \multicolumn{2}{|c|}{$\underline{1900}$} & \multicolumn{2}{|c|}{$\underline{1910}$} & \multicolumn{2}{|c|}{$\underline{1920}$} & \multicolumn{2}{|c|}{1930} \\
\hline & $\begin{array}{l}\text { Linked } \\
\text { Sample }\end{array}$ & $\begin{array}{c}\text { Complete } \\
\text { Count } \\
\text { Sample }\end{array}$ & $\begin{array}{l}\text { Linked } \\
\text { Sample }\end{array}$ & $\begin{array}{c}\text { Complete } \\
\text { Count } \\
\text { Sample }\end{array}$ & $\begin{array}{l}\text { Linked } \\
\text { Sample }\end{array}$ & $\begin{array}{c}\text { Complete } \\
\text { Count } \\
\text { Sample }\end{array}$ & $\begin{array}{l}\text { Linked } \\
\text { Sample }\end{array}$ & $\begin{array}{c}\text { Complete } \\
\text { Count } \\
\text { Sample }\end{array}$ \\
\hline \multicolumn{9}{|l|}{ Personal characteristics: } \\
\hline Mean age & 10.01 & 10.06 & 10.42 & 10.44 & 10.32 & 10.3 & 10.37 & 10.43 \\
\hline Median age & 10 & 10 & 10 & 10 & 10 & 10 & 10 & 10 \\
\hline Literate & 0.95 & 0.95 & 0.99 & 0.99 & 0.99 & 0.99 & 0.99 & 0.99 \\
\hline In school & 0.9 & 0.89 & 0.92 & 0.91 & 0.9 & 0.88 & 0.93 & 0.92 \\
\hline \multicolumn{9}{|l|}{$\begin{array}{l}\text { Household and family } \\
\text { characteristics: }\end{array}$} \\
\hline In urban area & 0.97 & 0.97 & 0.98 & 0.98 & 0.98 & 0.98 & 0.98 & 0.98 \\
\hline Home owned & 0.34 & 0.31 & 0.37 & 0.33 & 0.4 & 0.36 & 0.36 & 0.34 \\
\hline Mother present & 0.96 & 0.95 & 0.95 & 0.94 & 0.96 & 0.95 & 0.97 & 0.97 \\
\hline Father present & 0.9 & 0.88 & 0.89 & 0.88 & 0.9 & 0.9 & 0.93 & 0.93 \\
\hline Mother literate if present & 0.92 & 0.89 & 0.92 & 0.89 & 0.92 & 0.88 & 0.95 & 0.94 \\
\hline Father literate if present & 0.94 & 0.92 & 0.95 & 0.93 & 0.94 & 0.92 & 0.97 & 0.96 \\
\hline Father occscore if present & 21.93 & 21.76 & 27.75 & 27.25 & 20.77 & 20.45 & 24.76 & 24.61 \\
\hline Observations & 585,386 & $1,948,639$ & 850,923 & $2,554,211$ & $1,131,162$ & $3,207,363$ & $1,521,739$ & $3,917,714$ \\
\hline
\end{tabular}

Notes: This table reports differences in means between individuals who were linked to the 1940 census, as described in the text, and the entire sample that we attempted to link from the complete count censuses. The census question on literacy only applied to persons 10+ years of age. Father's occupational score is included if the father is present and an occupational score is given. 
Table A.II. Effect of school resources for cities with population below 250,000 in 1900

\begin{tabular}{lccccc}
\hline Dependent variable: & $\begin{array}{c}\text { Educational } \\
\text { attainment }\end{array}$ & $\begin{array}{c}\text { Pr(8th grade } \\
\text { completed =1) }\end{array}$ & $\begin{array}{c}\text { Pr(High school } \\
\text { graduate = 1) }\end{array}$ & $\begin{array}{c}\text { Log(weekly } \\
\text { wage })\end{array}$ & $\begin{array}{c}\text { Pr(white-collar } \\
\text { employment = 1) }\end{array}$ \\
\hline
\end{tabular}

(1) (2) (3) (4)

(5)

Panel A: OLS estimates for cities under 250,000 in 1900

$\begin{array}{lccccc}\text { Log(expenditures per pupil) } & 0.0600 & 0.0122 * * * & -0.00251 & 0.00836 & -0.0107 * * \\ & (0.0521) & (0.00460) & (0.0106) & (0.00714) & (0.00458) \\ & & & & & \\ \mathrm{N} & 893220 & 893220 & 893220 & 893220 & 893220 \\ \text { Cities } & 368 & 368 & 368 & 368 & 368\end{array}$

Panel B: 2SLS estimates for cities under 250,000 in 1900

\begin{tabular}{lccccc} 
Log(expenditures per pupil) & $1.517 * * *$ & $0.109 * * *$ & $0.256 * * *$ & $0.0925 * *$ & -0.0314 \\
& $(0.424)$ & $(0.0343)$ & $(0.0767)$ & $(0.0402)$ & $(0.0255)$ \\
& & & & & 33.26 \\
First stage F-statistics & 33.26 & 33.26 & 33.26 & 893220 & 893220 \\
$\mathrm{~N}$ & 893220 & 893220 & 893220 & 368 & 368 \\
Cities & 368 & 368 & 368 & 368 \\
\hline
\end{tabular}

Notes: Panels A and B provide estimates of equation (4) in the text. The key treatment variable, log(expenditures per pupil) is average per pupil spending (in real 1930 dollars) during school-age years (ages 6-14). Expenditures per pupil is the sum of expenditures on teachers, supervisors, capital, and other expenditures all divided by the average daily attendance in a school. All regressions control for: city of education fixed effects, cohort fixed effects, mother's literacy (mother literate, mother illiterate, and mother not present), father's literacy (father literate, father illiterate, and father not present), mother's occupation (dummies), father's occupation (dummies), and the average percent of a city's population that reports working in one of the following industries during a child's school-age years: white collar (professional, manager, clerk, or salesmen), craftsman, operator, service worker, laborer, or farmer. Non-occupational responses are the omitted category. These percentages were constructed from the 1900-1930 IPUMS (Ruggles et al. 2018) complete count data and are interpolated inbetween census years. The excluded instrument in the second stage regression is (the number of years of exposure to post-WWI schooling) $\mathrm{x}$ (the log of the German share of a city's population in 1910). The number of years of exposure to post-WWI schooling is defined as the number of school-age years (ages 6-14) that occurred during or after 1917. Standard errors are in parentheses. 
Table A.III. Robustness to dropping younger cohorts

\begin{tabular}{|c|c|c|c|c|c|}
\hline \multirow[t]{2}{*}{ Dependent variable: } & $\begin{array}{l}\text { Educational } \\
\text { attainment }\end{array}$ & $\begin{array}{c}\operatorname{Pr}(8 \text { th grade } \\
\text { completed = 1) }\end{array}$ & $\begin{array}{l}\text { Pr }(\text { High school } \\
\text { graduate }=1)\end{array}$ & $\begin{array}{l}\text { Log(weekly } \\
\text { wage) }\end{array}$ & $\begin{array}{c}\text { Pr(white-collar } \\
\text { employment = 1) }\end{array}$ \\
\hline & (1) & (2) & (3) & (4) & (5) \\
\hline \multicolumn{6}{|c|}{ Panel A: Baseline 2SLS estimates } \\
\hline Log(expenditures per pupil) & $1.649 * * *$ & $0.170 * *$ & $0.176 * * *$ & $0.145 * *$ & 0.0201 \\
\hline First stage F-statistics & 11.92 & 11.92 & 11.92 & 11.92 & 11.92 \\
\hline $\mathrm{N}$ & 1458074 & 1458074 & 1458074 & 1458074 & 1458074 \\
\hline Cities & 385 & 385 & 385 & 385 & 385 \\
\hline
\end{tabular}

Panel B: 2SLS estimates for 1894-1910 birth cohorts

\begin{tabular}{lccccc} 
Log(expenditures per pupil) & $1.398 * * *$ & $0.197 * * *$ & $0.117 * *$ & $0.169 * * *$ & 0.0484 \\
& $(0.418)$ & $(0.0763)$ & $(0.0499)$ & $(0.0604)$ & $(0.0309)$ \\
& & & & 12.6 & 12.6 \\
First stage F-statistics & 12.6 & 12.6 & 12.6 & 12.6 & 950477 \\
$\mathrm{~N}$ & 950477 & 950477 & 950477 & 950477 & 385 \\
Cities & 385 & 385 & 385 & 385 & 385 \\
\hline \hline
\end{tabular}

Notes: Panels A and B provide estimates of equation (4) in the text. The key treatment variable, log(expenditures per pupil) is average per pupil spending (in real 1930 dollars) during school-age years (ages 6-14). Expenditures per pupil is the sum of expenditures on teachers, supervisors, capital, and other expenditures all divided by the average daily attendance in a school. All regressions control for: city of education fixed effects, cohort fixed effects, mother's literacy (mother literate, mother illiterate, and mother not present), father's literacy (father literate, father illiterate, and father not present), mother's occupation (dummies), father's occupation (dummies), and the average percent of a city's population that reports working in one of the following industries during a child's school-age years: white collar (professional, manager, clerk, or salesmen), craftsman, operator, service worker, laborer, or farmer. Non-occupational responses are the omitted category. These percentages were constructed from the 1900-1930 IPUMS (Ruggles et al. 2018) complete count data and are interpolated in-between census years. The excluded instrument in the second stage regression is (the number of years of exposure to post-WWI schooling) $\mathrm{x}$ (the log of the German share of a city's population in 1910). The number of years of exposure to post-WWI schooling is defined as the number of school-age years (ages 6-14) that occurred during or after 1917. Standard errors are in parentheses. $* \mathrm{p}<0.1, * * \mathrm{p}<0.05, * * * \mathrm{p}<0.01$. 
Table A.IV. OLS and 2SLS estimates of expenditures per pupil on adult outcomes using exact name and age matching

\begin{tabular}{|c|c|c|c|c|c|}
\hline Dependent variable: & $\begin{array}{c}\text { Educational } \\
\text { attainment }\end{array}$ & $\begin{array}{c}\operatorname{Pr}(8 \text { th grade } \\
\text { completed = 1) }\end{array}$ & $\begin{array}{l}\text { Pr(High school } \\
\text { graduate = 1) }\end{array}$ & $\begin{array}{l}\text { Log(weekly } \\
\text { wage) }\end{array}$ & $\begin{array}{c}\operatorname{Pr}(\text { white-collar } \\
\text { job }=1)\end{array}$ \\
\hline & (1) & $(2)$ & (3) & (4) & (5) \\
\hline \multicolumn{6}{|l|}{ Panel A: Panel estimates } \\
\hline Log(expenditures per pupil) & $\begin{array}{l}0.132 * * \\
(0.0567)\end{array}$ & $\begin{array}{c}0.0119 \\
(0.00817)\end{array}$ & $\begin{array}{c}-0.000104 \\
(0.0105)\end{array}$ & $\begin{array}{c}0.0127 \\
(0.00979)\end{array}$ & $\begin{array}{c}-0.0116 \\
(0.00855)\end{array}$ \\
\hline \multicolumn{6}{|l|}{ Panel B: 2SLS estimates } \\
\hline Log(expenditures per pupil) & $\begin{array}{c}1.924 * * * \\
(0.593)\end{array}$ & $\begin{array}{l}0.172 * * \\
(0.0780)\end{array}$ & $\begin{array}{l}0.211 * * \\
(0.0882)\end{array}$ & $\begin{array}{l}0.162 * * \\
(0.0758)\end{array}$ & $\begin{array}{c}0.000350 \\
(0.0438)\end{array}$ \\
\hline First stage F-statistics & 10.81 & 10.81 & 10.81 & 10.81 & 10.81 \\
\hline $\mathrm{N}$ & 649310 & 649310 & 649310 & 649310 & 649310 \\
\hline Cities & 385 & 385 & 385 & 385 & 385 \\
\hline
\end{tabular}

Notes: Panel A provides estimates of equation (2) in the text. The key treatment variable, $\log ($ expenditures per pupil) is average per pupil spending (in real 1930 dollars) during school-age years (ages 6-14). Expenditures per pupil is the sum of expenditures on teachers, supervisors, capital, and other expenditures all divided by the average daily attendance in a school. All regressions control for: city of education fixed effects, cohort fixed effects, mother's literacy (mother literate, mother illiterate, and mother not present), father's literacy (father literate, father illiterate, and father not present), mother's occupation (dummies), father's occupation (dummies), and the average percent of a city's population that reports working in one of the following industries during a child's school-age years: white collar (professional, manager, clerk, or salesmen), craftsman, operator, service worker, laborer, or farmer. Non-occupational responses are the omitted category. These percentages were constructed from the 1900-1930 IPUMS (Ruggles et al. 2018) complete count data and are interpolated in-between census years. Panel B provides 2SLS estimates of equations (4) in the text. The excluded instrument in the second stage regression is (the number of years of exposure to post-WWI schooling) $\mathrm{x}$ (the log of the German share of a city's population in 1910). The number of years of exposure to post-WWI schooling is defined as the number of school-age years (ages 6-14) that occurred during or after 1917. Standard errors are in parentheses. ${ }^{*} \mathrm{p}<0.1, * * \mathrm{p}<0.05, * * * \mathrm{p}<0.01$. 
Table A.V. OLS and 2SLS estimates of expenditures per pupil on adult outcomes using unique names

\begin{tabular}{|c|c|c|c|c|c|}
\hline Dependent variable: & $\begin{array}{c}\text { Educational } \\
\text { attainment }\end{array}$ & $\begin{array}{c}\operatorname{Pr}(8 \text { th grade } \\
\text { completed = 1) }\end{array}$ & $\begin{array}{l}\text { Pr(High school } \\
\text { graduate = 1) }\end{array}$ & $\begin{array}{l}\text { Log(weekly } \\
\text { wage) }\end{array}$ & $\begin{array}{c}\operatorname{Pr}(\text { white-collar } \\
\text { job }=1)\end{array}$ \\
\hline & $(1)$ & (2) & (3) & (4) & (5) \\
\hline \multicolumn{6}{|l|}{ Panel A: Panel estimates } \\
\hline Log(expenditures per pupil) & $\begin{array}{c}0.151 * * * \\
(0.0533)\end{array}$ & $\begin{array}{l}0.0181 * * \\
(0.00716)\end{array}$ & $\begin{array}{l}0.00171 \\
(0.0101)\end{array}$ & $\begin{array}{c}0.0153 \\
(0.00945)\end{array}$ & $\begin{array}{l}-0.00450 \\
(0.00631)\end{array}$ \\
\hline \multicolumn{6}{|l|}{ Panel B: 2SLS estimates } \\
\hline Log(expenditures per pupil) & $\begin{array}{c}1.648 * * * \\
(0.477)\end{array}$ & $\begin{array}{l}0.179 * * \\
(0.0736)\end{array}$ & $\begin{array}{l}0.178 * * \\
(0.0741)\end{array}$ & $\begin{array}{l}0.159 * * \\
(0.0738)\end{array}$ & $\begin{array}{c}0.0257 \\
(0.0313)\end{array}$ \\
\hline First stage F-statistics & 11.57 & 11.57 & 11.57 & 11.57 & 11.57 \\
\hline $\mathrm{N}$ & 970950 & 970950 & 970950 & 970950 & 970950 \\
\hline Cities & 385 & 385 & 385 & 385 & 385 \\
\hline
\end{tabular}

Notes: Panel A provides estimates of equation (2) in the text. The key treatment variable, $\log ($ expenditures per pupil) is average per pupil spending (in real 1930 dollars) during school-age years (ages 6-14). Expenditures per pupil is the sum of expenditures on teachers, supervisors, capital, and other expenditures all divided by the average daily attendance in a school. All regressions control for: city of education fixed effects, cohort fixed effects, mother's literacy (mother literate, mother illiterate, and mother not present), father's literacy (father literate, father illiterate, and father not present), mother's occupation (dummies), father's occupation (dummies), and the average percent of a city's population that reports working in one of the following industries during a child's school-age years: white collar (professional, manager, clerk, or salesmen), craftsman, operator, service worker, laborer, or farmer. Non-occupational responses are the omitted category. These percentages were constructed from the 1900-1930 IPUMS (Ruggles et al. 2018) complete count data and are interpolated in-between census years. Panel B provides 2SLS estimates of equations (4) in the text. The excluded instrument in the second stage regression is (the number of years of exposure to post-WWI schooling) $\mathrm{x}$ (the log of the German share of a city's population in 1910). The number of years of exposure to post-WWI schooling is defined as the number of school-age years (ages 6-14) that occurred during or after 1917. Standard errors are in parentheses. ${ }^{*} \mathrm{p}<0.1,{ }^{* *} \mathrm{p}<0.05,{ }^{* * *} \mathrm{p}<0.01$. 


\section{Table A.VI. OLS and 2SLS estimates of expenditures per pupil on adult outcomes using unique and exact names and ages}

\begin{tabular}{|c|c|c|c|c|c|}
\hline Dependent variable: & $\begin{array}{c}\text { Educational } \\
\text { attainment }\end{array}$ & $\begin{array}{l}\operatorname{Pr}(8 \text { th grade } \\
\text { completed = 1) }\end{array}$ & $\begin{array}{l}\text { Pr(High school } \\
\text { graduate = 1) }\end{array}$ & $\begin{array}{l}\log (\text { weekly } \\
\text { wage) }\end{array}$ & $\begin{array}{c}\operatorname{Pr}(\text { white-collar } \\
\text { job = 1) }\end{array}$ \\
\hline & (1) & (2) & (3) & (4) & (5) \\
\hline \multicolumn{6}{|l|}{ Panel A: Panel estimates } \\
\hline Log(expenditures per pupil) & $\begin{array}{c}0.175^{* * *} \\
(0.0651)\end{array}$ & $\begin{array}{l}0.0181 * * \\
(0.00863)\end{array}$ & $\begin{array}{c}0.00475 \\
(0.0118)\end{array}$ & $\begin{array}{c}0.0204 * \\
(0.0120)\end{array}$ & $\begin{array}{l}-0.00998 \\
(0.00832)\end{array}$ \\
\hline \multicolumn{6}{|l|}{ Panel B: 2SLS estimates } \\
\hline Log(expenditures per pupil) & $\begin{array}{c}2.070 * * * \\
(0.632)\end{array}$ & $\begin{array}{l}0.212 * * \\
(0.0895)\end{array}$ & $\begin{array}{c}0.243 * * \\
(0.103)\end{array}$ & $\begin{array}{l}0.180 * * \\
(0.0858)\end{array}$ & $\begin{array}{l}0.00720 \\
(0.0463)\end{array}$ \\
\hline First stage F-statistics & 10.87 & 10.87 & 10.87 & 10.87 & 10.87 \\
\hline $\mathrm{N}$ & 474045 & 474045 & 474045 & 474045 & 474045 \\
\hline Cities & 385 & 385 & 385 & 385 & 385 \\
\hline
\end{tabular}

Notes: Panel A provides estimates of equation (2) in the text. The key treatment variable, $\log ($ expenditures per pupil) is average per pupil spending (in real 1930 dollars) during school-age years (ages 6-14). Expenditures per pupil is the sum of expenditures on teachers, supervisors, capital, and other expenditures all divided by the average daily attendance in a school. All regressions control for: city of education fixed effects, cohort fixed effects, mother's literacy (mother literate, mother illiterate, and mother not present), father's literacy (father literate, father illiterate, and father not present), mother's occupation (dummies), father's occupation (dummies), and the average percent of a city's population that reports working in one of the following industries during a child's school-age years: white collar (professional, manager, clerk, or salesmen), craftsman, operator, service worker, laborer, or farmer. Non-occupational responses are the omitted category. These percentages were constructed from the 1900-1930 IPUMS (Ruggles et al. 2018) complete count data and are interpolated in-between census years. Panel B provides 2SLS estimates of equations (4) in the text. The excluded instrument in the second stage regression is (the number of years of exposure to post-WWI schooling) $\mathrm{x}$ (the log of the German share of a city's population in 1910). The number of years of exposure to post-WWI schooling is defined as the number of school-age years (ages 6-14) that occurred during or after 1917. Standard errors are in parentheses. ${ }^{*} \mathrm{p}<0.1, * * \mathrm{p}<0.05, * * * \mathrm{p}<0.01$. 
Table A.VII. Effect of school resources on adult outcomes by nativity

\begin{tabular}{|c|c|c|c|c|c|c|c|c|c|c|}
\hline Dependent variable: & \multicolumn{2}{|c|}{$\begin{array}{l}\text { Educational } \\
\text { attainment }\end{array}$} & \multicolumn{2}{|c|}{$\begin{array}{c}\text { Pr }(8 \text { th grade } \\
\text { completed = 1) }\end{array}$} & \multicolumn{2}{|c|}{$\begin{array}{l}\text { Pr(High school } \\
\text { graduate }=1)\end{array}$} & \multicolumn{2}{|c|}{ Log weekly wage } & \multicolumn{2}{|c|}{$\begin{array}{c}\text { Pr(white collar } \\
\text { employment = 1) }\end{array}$} \\
\hline \multirow[t]{2}{*}{ Model: } & OLS & 2SLS & OLS & 2SLS & OLS & $2 \mathrm{SLS}$ & OLS & 2SLS & OLS & 2SLS \\
\hline & (1) & (2) & (3) & $(4)$ & (5) & (6) & (7) & (8) & (9) & (10) \\
\hline \multicolumn{11}{|c|}{ Panel A: Native Population } \\
\hline $\begin{array}{l}\text { Log(expenditures per } \\
\text { pupil) }\end{array}$ & $\begin{array}{l}0.122 * * \\
(0.0508)\end{array}$ & $\begin{array}{c}1.693 * * * \\
(0.477)\end{array}$ & $\begin{array}{l}0.0152 * * \\
(0.00714)\end{array}$ & $\begin{array}{l}0.168 * * \\
(0.0698)\end{array}$ & $\begin{array}{c}0.0000300 \\
(0.00929)\end{array}$ & $\begin{array}{l}0.187 * * * \\
(0.0714)\end{array}$ & $\begin{array}{c}0.0101 \\
(0.00881)\end{array}$ & $\begin{array}{l}0.138 * * \\
(0.0677)\end{array}$ & $\begin{array}{l}-0.00699 \\
(0.00634)\end{array}$ & $\begin{array}{c}0.0169 \\
(0.0329)\end{array}$ \\
\hline $\begin{array}{l}\text { First stage F statistic } \\
\mathrm{N}=1,411,938\end{array}$ & NA & 11.69 & NA & 11.69 & NA & 11.69 & NA & 11.69 & NA & 11.69 \\
\hline \multicolumn{11}{|c|}{ Panel B: Immigrant Population } \\
\hline $\begin{array}{l}\text { Log(expenditures per } \\
\text { pupil) }\end{array}$ & $\begin{array}{l}0.0949 \\
(0.105)\end{array}$ & $\begin{array}{c}0.632 \\
(0.418)\end{array}$ & $\begin{array}{c}0.0119 \\
(0.0167)\end{array}$ & $\begin{array}{l}0.131 * * * \\
(0.0470)\end{array}$ & $\begin{array}{l}-0.0200 \\
(0.0173)\end{array}$ & $\begin{array}{l}-0.00237 \\
(0.0633)\end{array}$ & $\begin{array}{c}0.0417 * * \\
(0.0204)\end{array}$ & $\begin{array}{l}0.189 * * * \\
(0.0717)\end{array}$ & $\begin{array}{l}-0.0145 \\
(0.0197)\end{array}$ & $\begin{array}{c}0.0856 \\
(0.0584)\end{array}$ \\
\hline $\begin{array}{l}\text { First stage F statistic } \\
\mathrm{N}=46,136\end{array}$ & NA & 22.63 & NA & 22.63 & NA & 22.63 & NA & 22.63 & NA & 22.63 \\
\hline
\end{tabular}

Notes: Panel A and B provide estimates of equation (2) and (4) in the text. All regressions control for: city of education fixed effects, cohort fixed effects, mother's literacy (mother literate, mother illiterate, and mother not present), father's literacy (father literate, father illiterate, and father not present), mother's occupation (dummies), father's occupation (dummies), , and the average percent of a city's population that reports working in one of the following industries during a child's school-age years: white collar (professional, manager, clerk, or salesmen), craftsman, operator, service worker, laborer, or farmer. Non-occupational responses are the omitted category. These percentages were constructed from the 1900-1930 IPUMS (Ruggles et al. 2018) complete count data and are interpolated inbetween census years. The excluded instrument in the second stage regressions is (the number of years of exposure to post-WWI schooling) $x$ (the log of the German share of a city's population in 1910). The number of years of exposure to post-WWI schooling is defined as the number of school-age years (ages 6-14) that occurred during or after 1917.

Standard errors are in parentheses.

$* \mathrm{p}<0.1, * * \mathrm{p}<0.05, * * * \mathrm{p}<0.01$. 